\title{
WestVirginiaUniversity
}

THE RESEARCH REPOSITORY @ WVU

Graduate Theses, Dissertations, and Problem Reports

2017

\section{The Influence of Police Profanity on Public Perception of Excessive Force}

Christina Patton

Follow this and additional works at: https://researchrepository.wvu.edu/etd

\section{Recommended Citation}

Patton, Christina, "The Influence of Police Profanity on Public Perception of Excessive Force" (2017). Graduate Theses, Dissertations, and Problem Reports. 6387.

https://researchrepository.wvu.edu/etd/6387

This Dissertation is protected by copyright and/or related rights. It has been brought to you by the The Research Repository @ WVU with permission from the rights-holder(s). You are free to use this Dissertation in any way that is permitted by the copyright and related rights legislation that applies to your use. For other uses you must obtain permission from the rights-holder(s) directly, unless additional rights are indicated by a Creative Commons license in the record and/ or on the work itself. This Dissertation has been accepted for inclusion in WVU Graduate Theses, Dissertations, and Problem Reports collection by an authorized administrator of The Research Repository @ WVU.

For more information, please contact researchrepository@mail.wvu.edu. 
The Influence of Police Profanity on Public Perception of Excessive Force

Christina Patton, M. S.

Dissertation submitted to The Eberly College of Arts and Sciences at West Virginia University

in partial fulfillment of the requirements for the degree of

Doctorate of Philosophy in

Psychology

\author{
William Fremouw, Ph.D., Chair \\ Michael Asken, Ph.D. \\ Barry Edelstein, Ph.D. \\ Natalie Shook, Ph.D. \\ Melissa Blank, Ph.D. \\ Jeffrey Daniels, Ph.D. \\ Department of Psychology
}

Morgantown, West Virginia

2016

Keywords: excessive force, profanity, police, law enforcement, use of force

Copyright 2016 Christina Patton 


\begin{abstract}
The Influence of Police Profanity on Public Perception of Excessive Force
\end{abstract}

\title{
Christina Patton
}

Previous research has examined elements of police performance impacting community policing and police-citizen relationships, but no study has considered the impact of police use of profanity during arrest on public rating of force. Police profanity may negatively bias police-citizen interactions, and this bias could shape later interactions with community members, decrease the quality of police-community relations, or even result in public outcry over excessive use of force (White, Cox, \& Baseheart, 1994). Further, profanity increases recipient physiological arousal in some settings (LaPointe, 2006) and aggressive behavior, which may exacerbate risk to the officer during an arrest and lead to more violent outcomes. Given these important concerns, the aim of this study was to determine whether officer use of profanity during arrest led to public perception of excessive force, and to examine whether incident variables (i.e., gender of the subject and gender of the officer) affected this relation. The results indicated that force was determined to be more excessive when profanity was used, when the subject was a female, and when the officer was a female. Participants who rated force as excessive had significantly more negative attitudes about police and police use of force. These findings have direct implications for police training and suggest that if police avoid the use of profanity, this could result in more positive relationships with the public and fewer allegations of excessive force. Future researchers should further evaluate the nature and impact of gender biases against female police, as they may contribute to reduced opportunities, less frequent promotion, and reduced self-efficacy in female officers. 
Table of Contents

I. Title page......................................................

II. Abstract..................................................... ii

III. Table of contents.............................................. ii

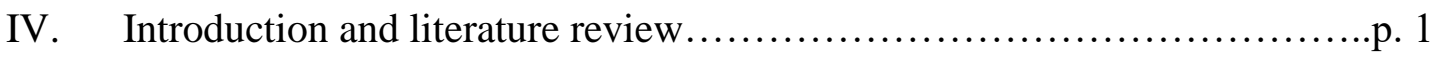

V. Statement of the problem and study aims...........................p. 15

VI. Methods......................................................... 16

VII. Results......................................................... 29

VIII. Discussion................................................... 36

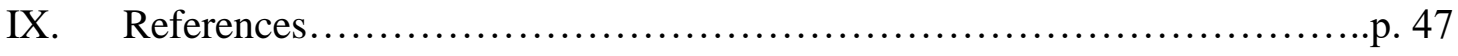

X. Tables...................................................... 64

XI. Figures.................................................... 70

XII. Appendix A................................................... 71

XIII. Appendix B.................................................. 75 
The Influence of Police Profanity on Public Perception of Excessive Force

\section{Introduction}

Scholars of law enforcement and police practices have described a "social contract" between police and the citizens they protect, such that police are charged with maintaining good order and decency and the public entrusts them to do so (Ariel, Farrar, \& Sutherland, 2014). As part of these duties, police contact 40 million citizens every year-a number that represents $16.9 \%$ of individuals over the age of 16 in the United States (Eith \& Durose, 2011). One out of every four individuals has more than one police contact in a year, and the majority of contacts are via traffic stops (44.1\%), being involved in a vehicle accident (7.5\%), or reporting a crime (3.5\%). When contact is made, the majority of citizens ( 9 out of 10) feel police acted properly (Eith \& Durose, 2011). A small percentage (1.4\%) have force used or threatened against them during arrest, and when that use of force is perceived negatively, it can impact later individual and community-level opinions of police (Eith \& Durose, 2011).

Part of the unique responsibility to protect the public requires the occasional use of force (UoF) to overcome resistance to authority (Micucci \& Gomme, 2005). When a show of force is deemed necessary, officers are expected to use only the level and type of force needed to reduce

or eliminate resistance. Many local and federal agencies establish their directives regarding UoF using a variation of the International Association of Chiefs of Police (IACP) standard, which includes passive interference (police presence on scene), commands (verbal orders to the public), physical coercion (grabs but no physical strikes to the subject), incapacitation (body strikes, TASERs, OC sprays, or blunt objects), and deadly force (Garner \& Maxwell, 1999; Robinson, 2011). Graham v. Connor (1989) established that the fourth amendment "reasonableness" standard should be invoked when analyzing police officer use of force - that is, whether the officer's actions are considered reasonable given the circumstances and facts known at the time, 
with the recognition that police are often asked to make split-second decisions when responding. Increasing levels of force are justified only when less intrusive means are ineffective or unreasonable in a given situation, and lethal force is justified only when a lack of its use would result in great bodily harm to the officer or public.

Officer UoF is constrained within this continuum in that officer actions are taken relative to subject actions. Often, officers will match the level of force to the level of the threat, but are authorized to match subject actions with the next highest level of force in order to eliminate a threat. Phillips (2010) gave several illustrations of this dynamic. He postulated that if a subject, for example, attempts to argue with an officer with the intent to avoid arrest (verbal resistance), the officer is within his/her means to parry with verbal commands until subject resistance either increases (mandating an increase in UoF level to physical coercion) or submits. Similarly, if a subject brandishes a knife in a standoff with police, officers are permitted to respond with matching lethal force (i.e., a firearm) in order to protect the safety and security of citizens in their area of responsibility.

\section{Excessive force}

Excessive force occurs when officers use an amount of force greater than what is needed to gain compliance in a situation (Adams, 1995; Crank \& Caldero, 2000; Micucci \& Gomme, 2005; Worden, 1995), more force than an "experienced" officer would employ in that situation (Klockars, 1996), or more force than what is recommended by administrative, professional, or legal guidelines (McElvain \& Kposowa, 2004). Often, the variables dictating the appropriate level of force are not immediately clear to bystanders, and establishing the "appropriate" UoF is made difficult by the fact that there is no consensus on a precise definition of "excessive."

Researchers have utilized a definition focused on citizen perceptions of excessive force (Durose, 
Schmitt, \& Langan, 2005) or number of citizen complaints against police (Adams, 1999; Harris, 2010), making conclusions about UoF problematic because some may be prone to initiate a complaint for retaliation or in response to force that was actually appropriate (Ariel et al., 2014; Harris, 2010). Force may also be described as excessive if some force is justified at incident initiation but the level of force used becomes unreasonable at some point during the incident (Phillips, 2010). Some scholars have remarked that this is different from "unnecessary force," or when an officer employs force when no force is justified (Ariel et al., 2014) - for example,

physically striking a subject securely in custody (Skolnick \& Fyfe, 1993). Commonly, legitimate UoF is conceptualized as one end of a spectrum, with police brutality and/or excessive force at the other (McElvain \& Kposowa, 2004).

\section{What is excessive force?}

Because definitions of excessive force vary, it is somewhat difficult to estimate true prevalence of arrests resulting in more force than is deemed appropriate. Many law enforcement agencies and the President's Commission on Law Enforcement and Administration of Justice in $1976^{1}$, have disagreed on what constitutes “improper," “excessive," or "unnecessary” force. Whether force is excessive is often a matter of opinion, and typically, the public's definition is much broader than that of police (Cao \& Huang, 2000). However, many studies have illustrated that physical force of any kind is used very rarely by police, and when it is, it rarely results in citizen complaints of excessive force. Langan, Greenfield, Smith, Durose, and Levin (2001) found that of 43 million police contacts with citizens in 1999, only one percent involved force or threat of force. Similarly, Alpert and Dunham (1999) found that of 150,841 police contacts made in a Florida jurisdiction in 1995, only seven excessive force complaints were filed. Many others

\footnotetext{
${ }^{1}$ For more on this, see Adams (1996) or Ariel et al. (2014).
} 
have found officer UoF during arrest to be as low as 1\% (Adams, 1996; Durose et al., 2005), and when it is used, it is most commonly pushing, shoving, or grabbing the subject (Holmes, 2000). Injuries are typically only minor abrasions or cuts/bruises (Adams, 1999; Alpert \& Dunham, 1999). Overall, officers do not often use physical force during arrest, but when they do, $8 \%-10 \%$ (Hickman, 2006; Pate \& Fridell, 1993; Perez, 1994; Wagner, 1980) to as much as one-third (Friedrich, 1980; Worden, 1995) of these arrests are determined to contain excessive force or warrant officer disciplinary action. Of those people who were the subjects of police force or who were threatened by police force, the majority $(74.3 \%-75 \%)$ report later that they felt the level of force was excessive (Eith \& Durose, 2011; Hyland, Langton, \& Davis, 2015) and notably, 42\% (Eith \& Durose, 2011) and 75\% (Hyland et al., 2015) of people whose interactions with police included shouting or cursing felt that was excessive. Although the need for physical force during arrest is rare, when it is used it is often viewed as inappropriate by not only the individual being arrested, but also the public observing the interaction.

Of the research focusing on variations in UoF, very few have examined use of excessive force. Instead, many studies have examined the relation(s) between officer UoF and characteristics of the officer, subject, situation, or environment (Phillips, 2010). Officers are more likely to use physical force if a subject is: young (Terrill \& Mastrofski, 2002; Terrill, Paoline, \& Manning, 2003); African-American (Kaminski, DiGiovanni, \& Downs, 2003; Schuck, 2004; Worden, 1995); male (Garner, Buchanan, Schade, \& Hepburn, 1996; Kaminski et al., 2003); of lower socioeconomic status (Terrill \& Mastrofski, 2002; Terrill et al., 2003); intoxicated (Garner, Maxwell, \& Heraux, 2002; Terrill \& Mastrofski, 2002; Terrill et al., 2003), or antagonistic toward police (Friedrich, 1980, Garner et al., 1996; Worden, 1995). With regard to officer characteristics, younger, less experienced officers are more likely than older, seasoned 
officers to use force (Kaminski et al., 2003; Terrill \& Mastrofski, 2002) and more likely to be the subject of UoF complaints (McElvain \& Kposowa, 2004) — though others have found no link between experience and UoF (Garner et al., 1996; Worden, 1995). Most studies of officer gender or race have shown no significant effects (Garner et al., 1996; McElvain \& Kposowa, 2004; Worden, 1995), though one study found that female officers were less likely to garner complaints (Brandl, Stroshine, \& Frank, 2001). Some studies of education concluded that more educated officers are less often the subject of citizen complaints (Cohen \& Chaiken, 1972) and allegations of excessive force (Cascio, 1977), while others have found no effect at all (Croft, 1985). Certain aspects of an arrest situation, like subject involvement in a violent crime (Alpert, Dunham, \& MacDonald, 2004; Friedrich, 1980; Garner et al., 1996), subject possession of a weapon (Garner et al., 1996; Kaminski et al., 2003), and foot/car pursuit of subject (Kaminski et al., 2003) predict officer UoF. Interestingly, one study found that contacts initiated by the officer, versus those initiated by the subject, were more likely to result in UoF (Terrill et al., 2003). More productive officers, by virtue of frequently "disrupting the felonious plans of many disgruntled (and complaint prone) offenders" (Toch, 1995, p. 100), may be more subject to complaints of excessive force simply because they arrest more individuals.

Of the previous studies examining officer variables related to general citizen complaints or complaints of excessive force, several identified aspects of unprofessional police conduct more explicitly tied to citizen discontent. For cases involving officers from a large northeastern police department with medium to high rates of citizen complaints from 1987-2001, improper police action, unprofessional conduct, and excessive force were described as the top three reasons for filing by the department's Internal Affairs Bureau (Harris, 2010). The use of a "more aggressive" police stance (Holmes \& Smith, 2012, p. 345) and discourtesy toward citizens 
(Terrill \& McCluskey, 2002), result in more frequent citizen complaints as well. Sometimes referred to as "extra-legal aggression," police actions which violate departmental regulations and may come to cause psychological or physical harm to citizens are viewed on a spectrum, with excessive physical force on one end and racially-motivated traffic stops, racial slurs or hate language, and profanity on the other (Holmes \& Smith, 2012). Verbal extra-legal aggression, including racial slurs, gratuitous threats and profanity, is humiliating, frightening, and degrading to citizens (Brunson \& Miller, 2006).

\section{Profanity}

The nature of citizen complaints referencing verbal aggression is not often described in the literature, but language typically identified as profane or obscene is frequently used by police to refer to subjects-sometimes in front of those citizens during an interaction (White et al., 1994). Some case-oriented training materials readily available to police include descriptions of incidents including profanity, which is often directed at a subject. When this occurs, citizens have cited profanity as one of the key factors in their negative evaluation of police (Cox \& White, 1988), which has the long-term effect of souring police-community relations.

Definition of profanity. Any consideration of the impact of police use of profanity in interactions with the public is immediately halted by the need for a definition of what type of language is considered profane. What is profane often depends not just on speaker intent, but also on cultural elements, individual interpretation, and the context. Calling someone a "mean bastard," for example, may be viewed as an insult that invites a rebuttal, but could also be a term expressing admiration or affection (Baseheart \& Cox, 1993). Patrick (1901) was probably the first to conceptualize profanity as a type of "ejaculatory swearing," or a word or phrase "often connected with religion or other sacred things, having no logical connection with the subject at 
hand, and indicative of strong feeling, such as anger or disapproval" (Patrick, 1901, p. 114). Patrick's classification system included the names of deities, names connected with religious practices, names of saints and sacred places, names "connected to the future life" (hell, damn), and vulgar words and expletives (Patrick, 1901, p. 115). Later conceptualizations of what was considered profane reflected changing social environments and a reduced usage of religionrelated profanity (Mabry, 1974). Rossiter and Bostrom (1969) created a three-tier system of profanity based on increasing offensiveness and decreasing usage: religious derivations (e.g., hell, goddamn, Jesus), excretory derivations (e.g., shit, piss, crap), and sexual derivations (e.g., fuck, cock, cunt) that others have utilized in their own research (Baudhuin, 1973; Cameron, 1969).

Profane language use begins as early as childhood and persists into old age, even in patients with Alzheimer's disease, other types of dementia, and aphasia (Jay, 1992, 2000, 2009). Frequency estimates of profanity have ranged from $0.5 \%-0.7 \%$ of spoken conversations (McEnery, 2006; Mehl \& Pennebaker, 2003) and $0.2-0.3 \%$ of verbiage in social media and in chat rooms (Subrahmanyam, Smahel, \& Greenfield, 2006; Thelwall, 2008). Socially low-ranking speakers have been found to use more profanity than high-ranking speakers (McEnery, 2006); agreeable and conscientious individuals less than other Big 5 personality types (Mehl, Gosling, \& Pennebaker, 2006); and college students more than adults in the general population (Nerbonne \& Hipskind, 1972). From 1986-2006, the most commonly used profane words were fuck, shit, hell, damn, goddamn, Jesus Christ, ass, oh my god, bitch, and sucks, but two words (i.e., fuck, shit) accounted for one-third to one-half of all examples of profanity in the sample examined (Jay, 1992, 2000; Jay \& Janschewitz, 2008). 
Function of profanity. In 1901, Patrick asked two questions: Why do we swear, and when we choose to swear, what dictates the words that we choose? In the years since this early work, researchers have concluded that people swear for a variety of reasons, many of which are not immediately evident to the person doing the swearing. Some sources describe profanity as a means of social bonding or promotion of solidarity (LaPointe, 2006; Selnow, 1985; Vincze, 1985); a way to cope with physical or emotional pain (Stephens \& Umland, 2011); a practice of catharsis/tension reduction (Rassin \& Muris, 2005; Rothwell, 1971); to convey strong emotion (Vingerhoets, Bylsma, \& de Vlam, 2013); or a way to communicate power and control or to establish a dominant-submissive relationship (Selnow, 1985; Zimmerman \& West, 1979). Profanity has several more negatively-tinged uses, such as alienation of others from group membership (Selnow, 1985); to defy authority figures (Paletz \& Haris, 1975; as a way of labeling others (Warshay \& Warshay, 1978); a conveyance of impending aggression (Vingerhoets et al., 2013); or as a means of degrading or humiliating other individuals (Paletz \& Haris, 1975).

With regard to police use of swearing, officers may choose to do so for a number of reasons. White et al. (1994) discussed how an officer may use profanity: 1) when attempting to bond with other officers, 2) as a way to vent frustration after volatile events, 3) in order to gain the attention of a subject, 4) to establish a "social distance" (p. 234) from the subject that results in dehumanization sometimes necessary to enact an arrest, 5) to label and degrade the subject to strip away incident complexity, and 6) to dominate or control the subject in an arrest situation. While officers may not intend to offend when using profanity, the end result could potentially be greater alienation from the police, community polarization, a clouding of the issues at hand postarrest, or a slash to the officer's credibility. 
Profanity's influence on others. Though people probably have used profanity as long as language has existed (LaPointe, 2006), there is a scarcity of research on its impact when utilized by law enforcement officials. Most of the research pertaining to profanity is found within the social psychology, linguistics, or behavioral health literatures, and analyzed the relation between profanity use and both negative and positive effects. Years of research on the physiological impacts of profanity have revealed that merely hearing or reading profane language can result in a host of physical effects, including autonomic arousal (Bowers \& Pleydell-Pearce, 2011), faster heart rate (Stephens \& Umland, 2011), blushing, trembling, changes in respiration, increased Galvanic skin response, and in some, loss of bowel or bladder function (LaPointe, 2006). However, swearing also produces psychological effects for those using it and those exposed to it. Many researchers have established that profanity in a professional capacity can lead to unfavorable or outright negative evaluations of performance. In studies analyzing the effect of counselor profanity on patient perceptions, several have concluded that profane language during a therapy session can lead to the idea that the counselor is less credible, effective or satisfying (Heubusch \& Horan, 1977); less trustworthy (Phillips \& Kassinove, 1987); less physically attractive (Paradise, Cohl, \& Zweig, 1980); disrespectful, unprofessional, and insensitive to client needs (Kottke \& MacLeod, 1989); and can potentially elicit less therapeutic compliance (Phillips \& Kassinove, 1987; Sazer, 1990). Others, however, have found that therapist profanity during sessions can have a positive effect because it creates an impression of the therapist as more effective and relatable (Wiley \& Locke, 1982). With regard to other professional capacities, including college faculty and those interviewing for a new position, swearing is linked to perceptions of unethical behavior (though this perception was only true for faculty and not students; Morgan \& Korschgen, 2001) and negative first impressions (Powell et al., 1984). 
Despite findings that profanity use leads to perceived unprofessionalism and a lack of constraint, some researchers have found that profanity does, in fact, lend credibility to one's arguments. In several studies, a public speaker was found more effective (Howell \& Giuliano, 2011); more persuasive and intense (Scherer \& Sagarin, 2006); and credible and believable (Rassin \& Van der Heiden, 2005) if he/she used profanity in an argument. In a study with conflicting results, the use of profanity in verbal communication led to the perception of decreased credibility (Bostrom, Baseheart, \& Rossiter, 1973), though this result only held true for males and not females. In these studies, the authors used varying amounts of profanity and profanity intensity, making it difficult to determine whether there is a threshold at which profanity is no longer viewed positively.

Research focused on long-term effects of exposure to profanity yields conclusions that profanity desensitizes individuals to aggression and may lead to reciprocal aggression from others. In a study of exposure to profanity via the media, Coyne, Stockdale, Nelson, and Fraser (2011) found that attitudes toward profanity mediated the relation between exposure to profanity via the media and later use of profanity and physical and relational aggression. Similarly, HolzIvory and Kaestle (2013) concluded that profanity used by characters in violent video games increased players' hostile expectations, which was identified as a precursor to violent or aggressive behavior. Others suggest that profanity use and/or exposure is associated with more aggressive personality types, is often considered a problem behavior for children, and can induce a numbing effect on typical emotional responding (Coyne et al., 2011). Such research is used as one means of justifying censorship of media containing profane language, and has incited debates regarding freedom of speech and the need to protect youth from this type of media exposure (Buckley \& Anderson, 2006; Wolfe, 1992). 
Johnson and Lewis (2010) attempted to explain why profanity affects people negatively using "expectancy violations" theory. Burgoon (1993) hypothesized that an individual's expectations of behavior serve as "perceptual filters" (p. 32) through which social information is processed, and when an event occurs that contradicts that individual's perceptions, a violation occurs that refocuses attention on a social evaluation of the speaker (Floyd \& Voloudakis, 1999). Expectancies can be general, or held for people in general, or particularized - specific to an individual. A common general expectancy, for example, is that people who receive a gift should say "thank you," and when this does not occur, a negative social evaluation of the speaker occurs. The degree of violation is said to depend on a number of variables, but is commonly tied to communicator characteristics, like gender, speaker-subject relationship, and contextual information, like presence of others, surprise, or formality of the situation (Johnson \& Lewis, 2010). Due to the emotional impact and infrequency of swearing, as well as the social taboo swearing represents, Johnson and Lewis (2010) hypothesized that speaker use in formal situations would violate expectancies and be especially surprising for those hearing it ("hearers"). Their results suggested that more formal occasions (formal meetings versus social gatherings) and more intense swearing (i.e., fuck versus shit or that sucks) significantly predicted surprise and later evaluation of the speaker as incompetent. Their results suggest that profanity is most jarring when it violates an individual's perspective regarding how and when it should be used, and this effect is especially true when the speaker is involved in some type of formal process and uses stronger language.

\section{Gender and profanity}

Gender is one of the most researched areas with regard to profanity usage and influence (Johnson \& Lewis, 2010), but results have been inconclusive. Earlier research appears to 
categorize more significant differences than more recent research, and yet a few trends emerge. Jespersen (1922) remarked that men swear and use slang and coarse language more often than women, and Kramer (1975) also found that women reported using fewer curse words than men (though the researchers did not differentiate between use of profanity in public versus private settings). With interest to perceptions of profanity, Selnow (1985) found that females tended to view its use as more inappropriate than men across a variety of situations. Females also reported using profanity less often than men and less frequently reported that profanity could be used as a demonstration of power or to make a user socially acceptable. Given research like this, De Klerk (1991) once commented, "It is hardly surprising that a stereotype has evolved in which men (forceful, active, hard, and dominating) do all the swearing, while tactful, sensitive, attractive, submissive females cower, shocked, in the background" (p. 158).

Some researchers have concluded that use of expletives by women rather than men leads to a negative evaluation by others (De Klerk, 1991; Lakoff, 1973; Rasmussen \& Moely, 1986) based on the idea that expletives, especially stronger ones, are prototypically masculine in nature. Others found no gender differences at all in terms of attributes applied to speakers using profanity (Johnson \& Lewis, 2010; Mulac, 1976), and in one study, that females were perceived as more credible than males when using profanity (Bostrom et al., 1973). Howell and Giuliano (2011) found that not only were males indifferent to profanity when females were not in a mock sports coach scenario, but males rated the use of profanity as ineffective when a team was made up of females only_ perhaps reflecting a long-documented social expectation that when women are present, men should not swear (Kaye \& Sapolsky, 2009). Still others suggest that gender of the audience is more important than gender of the speaker using profanity. Research on benevolent sexism (Glick \& Fiske, 1996) captured the idea that men may be offended by 
profanity used toward women, but not other men, because they feel as if women should be shielded from obscenity. Women, who do not uphold the same ideals of chivalry, may not be as affected by profanity when viewing its use as an outsider.

Recent research has suggested that gender biases documented in earlier research have begun to decline (Bailey \& Timm, 1976; Ginsburg, Ogletree, \& Silakowski, 2003; Jacobi, 2014; Johnson \& Lewis, 2010; Staley, 1978), perhaps as a function of shifting perceptions of social influence and power in the workforce. Some have concluded that females now curse almost as much as males, and the intensity of the words they choose is roughly similar (Bayard \& Krishnayya, 2001; De Klerk, 1991).Today, gender differences and profanity use are often characterized as existing on a "cursing continuum" where significant overlap between men and women (Jacobi, 2014, p. 265). Despite this, it is still unclear how the increasing acceptance of female use of profanity may affect perceived effectiveness or persuasiveness.

\section{Police use of profanity}

Surprisingly, research focusing on profanity's use in law enforcement settings is almost non-existent. Of the few articles that mention police profanity (Baseheart \& Cox, 1993; Cox \& White, 1988; White, 2002), conclusions vary widely. White (2002) described how, for example, police use of profanity is often dismissed as a normal part of police culture. Others have remarked that police use of "tactical language" serves the purpose of effectively bringing about a response from uncooperative suspects (Mather, 2015). White, Cox, and Baseheart (1988) reported that a significant proportion of their sample of community respondents $(12.2 \%)$ indicated that police had directed profane language toward them, and this usage resulted in later negative evaluations of police. In the only study directly focusing on impact of officer profanity, Baseheart and Cox (1993) found that when police officers used profanity in a mock traffic stop 
scenario, participants rated them as less friendly, less professional, and less fair than if the officer did not use profanity — regardless of gender of the officer. This is especially notable because in this study, the officer in question used only one swear word, and yet the negative main effects persisted. ${ }^{2}$ Despite this finding, officers were described as more qualified and more dynamic when using profanity, perhaps tied to the fact that participants related profanity use to masculinity, and the role of police is one typically aligned with masculine features (Baseheart \& Cox, 1993). In their final remarks, the authors also questioned whether their positive results may have been related to the artificiality of the experiment, in that scenarios were designed to omit any other paralinguistic cues of hostility associated with profanity and did not detract from the overriding perception of officer professionalism; thus, the profanity did not seem as negative.

When expletives are used by law enforcement officers on duty when interacting with community members, profanity is cited as one of the factors most significant in their negative evaluation of the police (Cox \& White, 1988; White et al., 1988). This negative evaluation may later result in alienation from the police, police misconduct allegations, perception that the officer lost control during the arrest, or a "clouding of the issues" (p. 237) pertaining to the arrest (White et al., 1994). During the course of an arrest, profanity used by the officer may lead to aggressive behavior from the subject, which could lead to a necessary escalation of force and resulting injuries to the officer or subject.

The relation between police profanity and aggressive subject behavior was only recently recognized by policy makers and law enforcement leaders. The President's Task Force on $21^{\text {st }}$ Century Policing, for example, has provided a list of formal recommendations on professional police language, suggesting that "because offensive or harsh language can escalate a minor

\footnotetext{
${ }^{2}$ The authors did not include any measures of effect size in their analyses.
} 
situation, law enforcement agencies should underscore the importance of language used and adopt policies directing officers to speak to individuals with respect" (President's Task Force on $21^{\text {st }}$ Century Policing, 2015, p. 46, para 1). However, the extent to which police departments have adopted this guidance or created training in line with these recommendations is unclear.

\section{Statement of the problem and study aims}

Because of the importance of verbal communication in citizen complaints against the police and the enduring effects of negative attitudes toward police cultivated during verbal encounters (White et al., 1994), officer use of profanity during arrest represents a low frequency, high intensity act that may have long-term effects not immediately evident at arrest. Further, the citizen complaints generated by unprofessional language may incur large economic costs, corrode public trust of law enforcement figures, and degrade efforts to affect community policing procedures (Ariel et al., 2014; Skogan \& Hartnett, 1997). Officer use of profanity during arrest may even incite aggressive behavior from subjects, thereby endangering both parties and further aggravating potentially volatile situations. For these reasons, it is crucial to investigate the association between profanity and public perception of excessive force. Thus, the aim of this study was to examine whether individuals would be more likely to rate force as excessive when profanity was used by the arresting officer than when it was not used. The secondary aims were to determine whether gender of the officer, gender of the subject, or previous negative experiences with police would play a role in the perception of excessive force.

\section{Hypotheses}

Across the extant literature, it is suggested that profanity use by an individual in a professional capacity is viewed negatively (Kottke \& MacLeod, 1989; Morgan \& Korschgen, 2001; Paradise et al., 1980; Phillips \& Kassinove, 1987; Sazer, 1990). In law enforcement 
settings, these negative evaluations could lead to the perception that the police officer is incompetent (Johnson \& Lewis, 2010) or has a lack of control in an already-volatile situation (White et al., 1994), resulting in the perception of UoF beyond what is reasonable for the situation. Gender of the officer or subject may also impact these negative evaluations, due to expectancy violations regarding gender (Johnson \& Lewis, 2010) and/or concepts of benevolent and/or hostile sexism (Glick \& Fiske, 1996). For these reasons, the following hypotheses were proposed:

1) Profanity use by the officer would be associated with a higher rating of excessive force than when profanity was not used. This was tested by examining main effects of the profanity independent variable via an ANOVA.

2) Profanity use against a female subject would be associated with a higher rating of excessive force than when used against a male subject. This was examined by analyzing the interaction effect of the gender of the subject $\mathrm{X}$ profanity independent variables via an ANOVA.

3) Profanity use by a female officer would be associated with a higher rating of excessive force than when used by a male officer. This was tested by examining the interaction effect of the gender of the officer X profanity independent variables via an ANOVA.

\section{Method}

\section{Design}

The study was a $2 \times 2 \times 2$ factorial design with three independent variables: profanity during arrest (used or not used), gender of the police officer (male or female), and gender of the subject (male or female). The dependent variable was the participant's rating of excessive force on a 1-4 Likert-type scale (described below). 
Before signing up for the study, participants were given a brief description of the study and its requirements. They were then directed to the survey and provided with a consent form. Once they indicated that they understood the risks and benefits of participation and answered two comprehension questions correctly, they were directed to the study online. Participants were instructed to view a video recorded on a police car "dash camera" and to answer questions regarding their opinions about the video. They also completed a series of questionnaires assessing their demographic information, attitudes regarding police, and previous experiences with police. Upon study completion, participants were presented with a debriefing form explaining the intent of the study and provided with researcher contact information should they have questions or concerns about their participation.

\section{Pilot Study}

To ensure the fictional arrest videos were equivalent with regard to clarity and intensity, a pilot study was conducted using a sample of undergraduates from a large mid-Atlantic university. Participants were recruited from introductory psychology courses and granted extra course credit for their participation. They viewed a selection of arrest videos and answered a series of questions to determine the following: 1) attention to detail and comprehension of video content, 2) clarity of video images and audio, 3) video intensity, or the extent to which they viewed the scene as intense, and 4) the level to which each video was viewed as realistic.

The pilot study data was analyzed using one-way independent ANOVAs with video type (videos 1-8) as the independent variable and a series of dependent variables (intensity, audio clarity, picture clarity, and realism) assumed to have largely similar values across video type. Dependent variables were measured using a 1-4 Likert scale (i.e., "not at all clear" to "very clear"). Eighty-two students completed 336 video ratings (i.e., ratings for four videos each) with 
different presentations of the study variables of interest (i.e., videos had either a male or female officer, male or female subject, and profanity or no profanity). Twenty-four video ratings (7.1\% of sample) from were excluded from analysis because participants reported atypical issues with video streaming (e.g., subtitles in a foreign language, buffering problem, slow video loading) and/or that they accidentally skipped the videos, resulting in a final sample of 312 video ratings.

The pilot study videos differed significantly with regard to video intensity, $\mathrm{F}(7,304)=$ 2.035, $p=.051$, partial $\eta^{2}=.22$. Games-Howell post-hoc analyses revealed that videos containing profanity (videos 2, 4, 6, and 8) often garnered significantly higher ratings of intensity than videos without profanity, $\mathrm{F}(1,304)=35.25, p<.001$, partial $\eta^{2}=.10$. For example, video 1 (female officer, female subject, no profanity; $M=2.26, S D=.575$ ) was significantly less intense than video 4 (female officer, male subject, with profanity; $M=2.83, S D=.702 ; p=.041$ ), video 6 (male officer, female subject, with profanity; $M=3.18, S D=.786 ; p<.001$ ), and video 8 (male officer, male subject, with profanity; $M=3.16, S D=.687 ; p<.001)$. Gender of the officer and gender of the subject also affected rating of video intensity (gender of officer: $\mathrm{F}[1,304]=20.23$, $p<.001$, partial $\eta^{2}=.07$; gender of subject: $\mathrm{F}[1,304]=4.97, p=.026$, partial $\left.\eta^{2}=.02\right)$. Arrests by female officers $(M=2.38, S D=.71)$ and of female subjects $(M=2.55, S D=.82)$ were viewed as less intense than those by male officers $(M=2.75, S D=.83)$ or of male subjects $(M=$ $2.68, S D=.79)$. The gender of the officer $\mathrm{X}$ profanity, $\mathrm{F}(1,304)=8.398, p=.004$, partial $\eta^{2}=$ .03 , and gender of the subject $\mathrm{X}$ profanity interaction terms, $\mathrm{F}(1,304)=4.619, p=.024$, partial $\eta^{2}=.02$, were significant. Arrests where female officers used profanity $(M=2.54, S D=.84)$ were rated as significantly less intense than those in which male officers used profanity $(M=$ $3.17, S D=.77)$. Additionally, scenarios depicting the use of profanity when arresting a female $(M=2.86, S D=.93)$ versus a male subject $(M=3.04, S D=.76)$ were viewed as less intense. 
Gender of the officer was related to significantly lower rating of realism, $F(1,304)=$ $5.143, p=.032$, partial $\eta^{2}=.02$, with arrests by female officers $(M=2.32, S D=.95)$ viewed as significantly less realistic than those by male officers $(M=2.45, S D=.77)$. To see if participant gender had any relation to these main effects, it was included as an additional independent variable; however, it was non-significant for both realism, $\mathrm{F}(1,304)=1.16, p=.282$, partial $\eta^{2}=$ .004 , and intensity, $\mathrm{F}(1,304)=.388, p=.534$, partial $\eta^{2}=.001$. It is possible that these results could be affected by the fact that participants were presented with multiple videos, which could lead to regression to the mean or otherwise distorted ratings. However, given that none of the videos differed significantly with regard to audio or visual clarity, the study videos were not edited prior to the main study.

\section{Main Study Participants}

After IRB approval, data were collected from two samples. Sample 1 included college undergraduates recruited undergraduate students from the same mid-Atlantic university using Sona Systems - an online data collection tool designed to facilitate collegiate research using collegiate samples. Using Sona, faculty or student researchers can create and implement a study using previously-collected data from student participants. Participants are typically granted course credit or monetary reimbursement for their time. Sona's cloud-based platform allows for 24-hour access for participants and services approximately 900 customers in 25 countries (Sona Systems, Ltd., 2014) while also operating at low cost for study administrators.

The study and a brief description were advertised in undergraduate psychology courses via a Powerpoint slide and on the Sona website. To ensure a medium to large effect size at approximately $80 \%$ power (Cohen, 1988), 320 undergraduates (i.e., eight batches of 40 participants) aged 18 years or older from these courses completed the survey and were granted 
extra credit for their participation in Sample 1. Only WVU students who created a Sona account and requested to participate for extra course credit were given access to the study. Once they answered two questions designed to confirm that they read and understood the risks and benefits of participation in the study, they were directed to view the fictional arrest video and complete a series of questionnaires described below. Participants were also asked a series of "validity check" questions to ascertain whether they properly attended to study materials. After collecting data from 320 individuals, the survey was closed.

Participants for Sample 2 included 320 community adults over 18 years of age via Amazon's Mechanical Turk (M-Turk) survey system. M-Turk is an online platform allowing secure, rapid, and inexpensive data collection over the Internet. M-Turk has a user base of approximately 100,000 individuals in the U.S. who voluntarily complete tasks and surveys posted by researchers for monetary compensation. The system is used in hundreds of research studies and laboratories across the world and grants researchers a unique opportunity for data collection from a diverse sample. In fact, Burhmester, Kwang, and Gosling (2011) found M-Turk samples more representative of the U.S. population and significantly more diverse than undergraduate samples. Furthermore, the authors found data collected via M-Turk to meet acceptable psychometric standards, with reliability coefficients equivalent to those calculated with data from a more traditional sample. Thus, M-Turk affords the option to collect data from a large sample of participants representing varying ages and demographics, thereby eliminating the need to rely exclusively on undergraduate samples and extending researcher capabilities.

A brief description of the proposed study was advertised on the M-Turk homepage, on which interested users could select and complete studies for monetary compensation. Only users from the U.S. with $95 \%$ task approval and 50 or greater approved tasks were allowed to 
participate. Batches were released at three-hour intervals to ensure adequate representation from different time zones across the U.S. Once users selected this study for completion, they were directed to the study via Survey Monkey, the online host for the accompanying measures. Similar to Sample 1 participants, Sample 2 participants were asked to answer two questions confirming they read and understood the study's informed consent agreement. If they answered these questions correctly, they were directed to the arrest video and study measures. Sample 2 participants were also asked questions designed to serve as "validity checks" during administration of the questionnaires. Upon completion, these participants received $\$ 1.00$ compensation for their time. Given an estimate of 20-30 minutes for study completion, this amount is above the median hourly wage $(\$ 1.38)$ for tasks performed on M-Turk (Horton \& Chilton, 2010).

\section{Description of fictional arrest stimulus}

A fictional arrest was shown in a video designed to assess the impact of the independent variable (profanity) on the dependent variable (participant perception of excessive force). The arrest videos were pre-recorded by state troopers at the Pennsylvania State Police (PSP) Academy and depicted a fictional interaction between a trooper and subject during a traffic stop situation that was captured on the police vehicle's Mobile Video Recording (MVR) “dash camera" system. Four academy instructors (two male, two female) portrayed either the trooper or the subject in a series of four possible scenarios: male officer, male subject; male officer, female subject; female officer, female subject; or female officer, male subject. The same event was presented to separate audiences featuring one of two conditions - the physical arrest of the violator without the use of profanity by the trooper, or the physical arrest of the violator while the officer is using profane language. Because there was the potential for undue influence on 
responding due to questions about negative interactions with police, half of the participants viewed the arrest video before completing study measures, while the other half viewed the arrest video after completing study measures.

During the course of the stop, the subject was shown as passively resistant (i.e., resisting arrest without using physical force). The trooper attempted to control the subject using physical techniques, to which the subject responded aggressively. With regard to the type of profane language chosen for the video, the researchers reviewed Cameron's (1969) three-type ranking system: words having religious connotations (hell, goddamn), words indicating excretory functions or organs (shit, piss, asshole), and words suggesting sexual content or organs (fuck, prick). Previous research indicates that profanity with religious connotations is least offensive, while profanity with sexual connotations is most offensive (Baudhuin, 1973); thus, one word from this category (i.e., fuck) was interjected into the experimental condition script per recommendations noted in previous studies (Baseheart \& Cox, 1993) to achieve maximum effect. The setting of the arrest, a traffic stop, was chosen because it represents the mostfrequently reported type of interaction with police (Eith \& Durose, 2011). The depictions of an arrest were generally identical except for the addition of profanity in four of the eight videos. A more detailed description of the arrest video, including a non-profanity and profanity script, is available in Appendix A.

After completion of the video, participants answered a number of questions to determine how closely they were paying attention to the stimulus (e.g., color of the subject's car, subject and officer gender, reason for subject arrest). They were asked to rate their overall perception of the quality of the interaction between the trooper and the subject $(1=$ very positive, $2=$ somewhat positive, $3=$ somewhat negative, and $4=$ very negative), how intense they found the 
scene to be $(1=$ not at all intense, $2=$ slightly intense, $3=$ somewhat intense, and $4=$ very intense), and excessiveness of the level of force used during arrest $(1=$ not at all excessive, $2=$ slightly excessive, $3=$ somewhat excessive, and $4=$ very excessive $)$. Finally, participants were asked to make an overall decision regarding excessive force $(0=$ not excessive, $1=$ excessive $)$ to more closely mimic the decision they might make after viewing similar incidents involving police in the media. A text box was provided for participants to briefly describe what it was that impacted their decision regarding UoF.

\section{Self-Report Assessment Instruments}

The participants completed a battery of questionnaires that have been used in a number of published studies on attitudes toward law enforcement. All measures are available in Appendix B and are described below.

Demographics questionnaire. Using a demographic survey based on U.S. Census data (U.S. Census Bureau, 2013), participants were asked to describe their biographical data, including gender, race/ethnicity, education, relationship status, etc. This information was used to determine whether subject-level variables also influenced rating of excessive force in a series of exploratory analyses.

Given recent increases in media coverage of negative police interactions with the public and the possibility that this exposure may have predisposed participants to have negative attitudes about police, survey items were added to capture the extent to which participants have been exposed to elements of police behavior. Specifically, participants indicated whether they were ever arrested, knew someone who was arrested, or had family members or close friends who worked in law enforcement. They were also asked about whether they sought out stories about police on the television or internet. Finally, participants described whether they lived in an 
urban, suburban, or rural area, as there was potential for participants living in more urban areas to have more frequent interactions with police and/or exposed to more information about recent arrests.

Trust and Confidence in Police Scale (TCPS). The TCPS is a 111-item exploratory evaluation of community policing used by Rosenbaum, Schuck, Costello, Hawkins, and Ring (2005) to determine whether Chicago residents' opinion regarding local police were influenced by pre-existing attitudes about police shaped by direct and/or vicarious experiences with police. Rosenbaum et al. (2005) contacted 505 Chicago residents in 2001 and 2002 to assess: 1) general attitudes about police, 2) composite attitudes about local police, 3) how attitudes were shaped by experiencing interactions with Chicago police through others (vicarious experience), and 4) how attitudes were affected by an individual's own experiences with police (direct experience). Of the direct experiences, additional questions were asked about those initiated by the participants (citizen initiated) and those initiated by police (police initiated). Other questions asked about specifics of the contact with police, including race/ethnicity of the police officer or participants, whether physical force was used, etc.

The TCPS was adapted for this study by retaining questions about general and specific attitudes about police and removing unnecessary questions pertaining to specific details about contact with police. After extraneous items were omitted, the shortened version of the TCPS (TCPS-S) included two subscales: general attitudes about police and composite attitudes about local police. The general attitudes subscale includes 11 items and participants were asked to rate their level of agreement with statements about police behavior and performance, using a 1-4 item Likert scale $(1=$ strongly agree to $4=$ strongly disagree $)$. Seven items are reverse-scored. Total scores range from 11-44 with higher scores suggesting more negative attitudes about police in 
general. Per the description from Rosenbaum et al. (2005), the composite attitudes about local police subscale was created using three items from a community policing questionnaire developed by Skogan and Hartnett (1997) to assess citizen attitudes about police in Chicago. A factor analysis revealed that these were the most central items in the Skogan and Hartnett (1997) questionnaire and together formed internally consistent smaller scales $(\alpha=.74-.77)$ of the following: police responsiveness (How responsive are the police in your neighborhood to community concerns?), crime prevention (How good a job do you think the police are doing to prevent crime in your neighborhood?), and politeness of interactions with residents (In general, how polite are the police when dealing with people in your neighborhood?). Score options are specific to each question but higher scores are reflective of negative attitudes about police in the participant's local area. For example, when asked about police responsiveness, participants may select from the following responses: $1=$ very responsive, $2=$ somewhat responsive, $3=$ somewhat un-responsive, or $4=$ very un-responsive.

Rosenbaum et al. (2005) did not provide psychometric data for this assessment, nor did they provide a discussion on how the questions were built (other than the three items pulled from Skogan and Hartnett, 1997). One can assume that this was because it was used as an exploratory assessment of community attitudes in a manner not yet undertaken by other researchers. Unfortunately, this is typical of assessments of attitudes about police and police practices, and recent recommendations from the IACP reflect the need for a standard survey for use by local and national police agencies (IACP, 2015). Here, the TCPS-S was used as an exploratory assessment to identify covariates of public perception of excessive force (e.g., negative policespecific attitudes). 
Specific Trust in Police Department Scale (STPDS). The STPDS is a three-item selfreport scale designed to assess trust in police departments with regard to investigating police officers after citizen complaints (Lai, Zhao, \& Jihong, 2010). This subscale is one part of a larger questionnaire used by Lai et al. (2010) as a telephone survey to assess public attitudes regarding police in Houston, Texas in 2008. In this survey, participants were asked to evaluate the extent to which they trusted that the Houston Police Department would: 1) investigate complaints against its own employees; (2) investigate complaints against its own employees fairly; and 3) hold its officers accountable for the unauthorized use of Conducted Energy Devices (TASERs). Respondents were asked to rate their response on a Likert scale from 1 (strongly disagree) to 5 (strongly agree), and higher scores were associated with greater specific trust in the police. Cronbach's alpha for this subscale was 0.77 , indicating high congruence between the three items. A factor analysis with varimax rotation revealed high factor loadings (0.761-0.801) for these three items onto a single factor, and together, these items had an eigenvalue of 2.16 and captured $30.82 \%$ of the variance. Item descriptions seemed to capture subjects' specific trust in police practices.

As no measure exists that assesses specific public attitudes regarding police use of force, the existing measure was adapted to focus more broadly on unauthorized UoF-not just those incidents characterized by TASER use, but by other non-lethal (e.g., ASP baton, OC pepper spray) and lethal (e.g., firearm) response options. Three additional questions were added to determine the degree of certainty to which participants trusted that: 1) police officers would choose the appropriate amount of force for an arrest, 2) police departments would initiate an investigation if an officer was suspected of excessive force, and 3) an officer would be properly sanctioned for use of excessive force should he/she be found guilty of doing so. The revised 
STPDS with added UoF questions (STPDS-UoF) contains seven items and lower overall scores indicate less specific trust in police UoF. Like the TCPS-S, the STPDS-UoF total score was used as a covariate that could impact the association between profanity and perception of excessive force.

Ambivalent Sexism Inventory (ASI). The ASI is a 22-item self-report assessment of sexism developed by Glick and Fiske (1996) to assess both hostile sexism, or negative attitudes toward women due to the perception of control through feminist ideology or sexual seduction, and benevolent sexism, or a subjective positive orientation toward women that feels favorable but actually portrays women as weak and requiring male protection. Each item poses a statement about gender beliefs (e.g., Most women interpret innocent remarks or acts as being sexist, Most women fail to appreciate fully all that men do for them) and participants are asked to rate their level of agreement with the statement on a $0-5$ Likert-type scale $(0=$ disagree strongly to $5=$ agree strongly). High overall scores are associated with respondent ambivalence toward women. The two ASI subscales (HS and BS) are composed of three sources of gender ambivalence: paternalism, gender differentiation, and heterosexuality. The BS subscale is composed of three subscales: protective paternalism, complementary gender differentiation, and heterosexual intimacy. High HS scores are suggestive of negative attitudes and stereotypes about women, and high BS scores to positive attitudes and stereotypes about women. For this study, this measure was used to assess whether pre-existing sexist attitudes would influence the impact of profanity used during arrest on the participant's rating of excessive force.

A principal components analysis revealed that of 112 original items on the ASI, three factors emerged that seemed to align with the concepts of hostile sexism (Factor 1; eigenvalue $=$ 25.64), protective paternalism and heterosexual intimacy (Factor 2; eigenvalue $=6.30$ ), and 
complementary gender differentiation (Factor 3; eigenvalue $=3.45$ ). These factors accounted for $23 \%, 6 \%$, and $3 \%$ of the variance, respectively. The latter two factors converged in later analyses to form one factor: benevolent sexism. Exploratory factor analysis yielded on hostile sexism factor and three benevolent sexism factors. Later studies supported the idea that HS is best described as one factor, whereas BS is best described using three sub-factors.

With regard to reliability, the HS subscale evidenced acceptable reliability (.80-.92) across six studies (Glick \& Fiske, 1996). The BS subscale demonstrated somewhat lower alpha coefficients (.73-.85), which the authors related to the multidimensional nature of the subscale. The ASI has also demonstrated convergent, predictive, and discriminant validity, by virtue of overall ASI scores predicting ambivalent attitudes toward women, the HS scale correlating with negative attitudes toward and stereotypes about women, and the BS scale (for non-student men only) correlating with positive attitudes toward and stereotypes about women (Glick \& Fiske, 1996).

\section{Statistical Analyses}

Before running analyses, the previously-described measures of trust in police (general trust, composite trust, and specific trust in police use of force) were recoded to ease interpretation such that lower scores represented less trust across all measures. Next, missing data for demographic and self-report measure data was analyzed. However, given that participants were directed to answer every question and reminded that they could opt out of the study at any time should they feel uncomfortable answering a question, there was no missing data to examine. Univariate outliers were identified by examining standardized values, and extreme scores (i.e., those with standardized values greater than 3) were adjusted per recommendations from Tabachnick \& Fidell (2007). Descriptive statistics were calculated and 
bivariate correlational analyses employed to understand the relation between demographic variables (e.g., age, gender), historical variables (e.g., negative experiences with police), officer profanity, and perception of excessive force.

Between-groups comparisons were conducted using a three-way ANOVA to determine if there was an interaction effect between the three independent variables (profanity, gender of officer, gender of subject) on a continuous dependent variable (rating of excessive force). Ratings of excessive force when profanity was used during arrest was also compared by sample (i.e., undergraduates versus M-Turk users) using an independent samples t-test. Correlational and logistic regression approaches were used to understand which individual (e.g., age, racelethnicity, gender) and historical (e.g., negative attitudes about police) variables influenced membership to appropriate vs. excessive use of force groups. All statistical analyses were performed using PASW Statistics 18.0.3.

\section{Results}

Six hundred and forty participants were recruited for the main study. Six hundred and ten participants satisfactorily completed informed consent questions and were granted access to the study. Average survey completion time was 21.39 minutes $(S D=58.26)$. To ensure participants adequately attended to study stimuli, participants who took less than five minutes or more than 35 minutes (i.e., 15 minutes above and below the mean completion time) to complete survey were excluded $(n=44)$. Forty-four participants who answered less than $50 \%$ of the "validity check" questions correctly were also excluded, to yield a final sample of $n=522$ (253 students and 269 community adults).

Within this sample, only the quality of arrest video variable evidenced problems with univariate outliers (i.e., those with standardized values greater than 3). The quality of arrest 
video and rating of excessive force (continuous) variables evidenced significant issues with skew and kurtosis, suggesting a non-normal distribution. To correct for this, square root transformations were completed for both of these variables, which brought them within the acceptable range (i.e., less than or equal to 3.2 when dividing test statistic by standard error). Participant demographic information is detailed in Table 1. Psychology student and community adults were compared to each other using chi-square analyses. Students were significantly younger than community adults, $\chi^{2}(5, n=522)=452.91, p<.001$. The vast majority of students were ages $18-24$ years $(97.2 \%)$, whereas only $4.1 \%$ of adults were in this category. None of the student participants were older than 44 years old, but the adult sample contained 73 participants (27.1\%) older than 44 years old. The student sample contained significantly more female participants $(74.3 \%)$ than the adult sample $(51.3 \%), \chi^{2}(1, n=522)=$ $29.43, p<.001$. No significant differences emerged between samples with regard to racial status and both samples were characterized by a large proportion of Caucasian/White participants (adults, $82.2 \%$; students, $81.4 \%), \chi^{2}(5, n=522)=1.12, p=.953$. The difference in mean years of education between samples was examined using an independent sample t-test. Adults had significantly more education than undergraduate psychology majors, $t(520)=9.17, p<.001$, with a large effect size of $d=.80$. Significant differences emerged with regard to marital status, $\chi^{2}(6, n=522)=177.58, p<.001$, with fewer students reporting being married $(1.6 \%)$ than adults (40.5\%) and fewer adults (37.2\%) than students (83.8\%) reporting being single. With regard to description of their area of residence, students reported living in rural areas more than adults (36.8\% versus $21.9 \%$, respectively), and adults reported living in suburban (46.1\%) and urban (32\%) locations more often than students (39.1\% and $24.1 \%$, respectively), $\chi^{2}(2, n=522)$ $=14.18, p=.001$. 
Bivariate correlations between police-specific study variables are shown in Table 2. General trust in police $(r=-.126, p=.004)$, composite trust in police $(r=-.142, p=.001)$, and specific trust in police use of force $(r=-.161, p<.001)$ were significantly negatively associated with rating of force as excessive. General trust in police was significantly associated with composite trust in police $(r=.150, p=.001)$ and specific trust in police use of force $(r=.273, p$ $<.001$ ), and composite trust in police were significantly associated with specific trust in police use of force $(r=.554, p<.001)$. Viewing police news/media online was significantly negatively associated with specific trust in police use of force, $(r=-.110, p=.012)$, but the relation between reading news stories and trusting police use of force was non-significant $(r=-.063, p=.148)$. Knowing someone who was previously arrested and ever being arrested were negatively associated with both composite trust in police (knowing someone: $r=-.130, p=.003$; ever being arrested: $r=-.197, p<.001)$ and specific trust in police use of force (knowing someone: $r=$ $.094, p=.032$; ever being arrested: $r=.181, p<.001)$. Having a family member or friends working in law enforcement was not significantly associated with participant rating of force as excessive (family member: $r=-.055, p=.430$; friends: $r=-.035, p=.212$ ).

Participants' previous exposure to police and attitudes about police are displayed in Table 3. Community adults had significantly less frequent exposure to police than psychology students via print news stories $(75.1 \%), \chi^{2}(1, n=522)=7.932, p=.005$, or online news/media $(84 \%), \chi^{2}$ $(1, n=522)=6.0, p=.014$ (psychology students: $85 \%$ and $99.1 \%$, respectively). Community adults had significantly fewer family members $(8.2 \%), \chi^{2}(1, n=522)=27.76, p<.001$, and friends $(14.1 \%)$ working in law enforcement, $\chi^{2}(1, n=522)=57.79, p<.001$, than psychology students (25.3\% and 42.7\%, respectively). Psychology students (4.3\%) reported significantly fewer previous arrests than did community adults $(19.3 \%), \chi^{2}(1, n=522)=27.58, p<.001$. 
However, significantly more psychology students (86.6\%) than community adults (71\%) reported knowing someone who was previously arrested, $\chi^{2}(1, n=522)=18.73, p<.001$.

Table 4 shows the relation of attitudes about police to rating of force by sample. As anticipated after correlational analysis, community adults who described the force as excessive had significantly less positive composite attitudes about police $(M=5.83, S D=2.36)$ than did those who did not find force excessive $(M=6.42, S D=1.96), t(267)=2.146, p=.033$, with a small effect size of $d=.27$. Community adults who rated force as excessive were also significantly more likely than community adults who did not to have low specific trust in police use of force $(M=14.35, S D=8.5$ versus $M=17.13, S D=8.26), t(267)=2.559, p=.011, d=$ .33. Psychology students who described the force as excessive had significantly less positive specific trust of police use of force $(M=16.24, S D=6.16)$ than did students who did not find force excessive $(M=18.39, S D=5.78), t(251)=2.588, p=.011, d=.36$. Community adults evidenced significantly greater general trust of police $(M=14.93, S D=6.61)$ than did psychology students $(M=13.48, S D=5.56), t(520)=2.727, p=.007, d=.24$. However, psychology students displayed significantly greater specific trust in police use of force $(M=$ $16.83, S D=6.13)$ than community adults $(M=15.26, S D=8.50), t(520)=-2.398, p=.017, d=$ .21. There were no significant differences with regard to rating of force as excessive, $t(520)=-$ $1.823, p=.069, d=.14$.

A 2 (gender of officer: male, female) x 2 (gender of subject: male, female) x 2 (profanity: used or not used) x 2 (order of arrest video presentation: before or after study measures) between-subjects factorial ANOVA was performed on one continuous dependent variable: participant rating of excessive force. Homogeneity of variance was examined using Levene's test. Using an alpha level of .001 to evaluate violations of this assumption, the rating of excessive 
force (continuous) variable was statistically significant $(p<.001)$. However, as the largest variance was no more than four times the smallest variance, the results were still considered to be valid and the ANOVA robust to distributional violations (in accordance with standards recommended by Zar, 1996).

Results are displayed in Table 5. There were significant main effects for gender of officer, $\mathrm{F}(1,514)=4.73, \mathrm{p}=.03$, partial $\eta^{2}=.01 ;$ gender of subject, $\mathrm{F}(1,514)=14.99, p<.001$, partial $\eta^{2}=.03$; and profanity, $\mathrm{F}(1,514)=57.14, p<.001$, partial $\eta^{2}=.10$. Participant rating of excessiveness of force was significantly higher when the arresting officer was a female $(M=$ $1.70, S D=.28)$ compared to when the officer was a male $(M=1.66, S D=.31)$. Force was also rated as more excessive when the subject of the arrest was a female $(M=1.72, S D=.26)$ relative to a male $(M=1.63, S D=.32)$. Finally, profanity used during arrest led to significantly greater ratings of force as excessive $(M=1.77, S D=.26)$ than when profanity was not used $(M=1.58$, $S D=.30$ ). This effect remained significant even after including participant gender as a covariate, $\mathrm{F}(1,519)=53.034, p<.001$, partial $\eta^{2}=.09$. When profanity was used during arrest, participants rated the quality of the interaction between police and subjects as significantly less positive $(M=1.36, S D=.59$, versus $M=1.84, S D=.71$ without profanity), $\mathrm{F}(1,520)=69.99, p$ $<.001$, partial $\eta^{2}=.12$, and significantly more intense $(M=2.95, S D=.76, M=2.43, S D=.72$ without profanity), $\mathrm{F}(1,520)=66.183, p<.001$, partial $\eta^{2}=.11$. Several participants who rated force as excessive commented on how the officer in the scenario used "harsh" and/or "aggressive language," "cursed unnecessarily," "verbally attacked" the subject, or looked "unprofessional" or even "out of control" due to use of profanity. One participant stated that the officer's use of profanity suggested that she had "let herself be goaded, which led to an overreaction from the subject," and others that the officer's use of profanity seemed to suggest that he/she "wanted to 
escalate" the force of the arrest. An examination of the interaction plots showed that force was determined to be the most excessive when the officer was female and the subject was female, and the least excessive when the officer was male and the subject male (see Figure 1). No interactions were statistically significant: profanity X gender of officer, $\mathrm{F}(1,514)=1.906, p$ $=.168$, partial $\eta^{2}=.004$, profanity $\mathrm{X}$ gender of subject, $\mathrm{F}(1,514)=.738, p=.391$, partial $\eta^{2}=$ .001 , or gender of officer $\mathrm{X}$ gender of subject, $\mathrm{F}(1,514)=.260, p=.610$, partial $\eta^{2}=.001$.

Given the significant effect of gender of the subject and gender of the officer, participant total scores on the ASI were entered into an ANCOVA, along with the main effect variables, to determine whether the main effects would hold after controlling for gender bias. As shown in Table 6, total ASI score was not a significant predictor of excessive force, $\mathrm{F}(1,513)=1.411, p$ $=.235$, partial $\eta^{2}=.003$, and after including it as a predictor, gender of the officer, $\mathrm{F}(1,513)=$ $5.075, p=.025$, partial $\eta^{2}=.01$, and gender of the subject, $\mathrm{F}(1,513)=15.122, p<.001$, partial $\eta^{2}=.03$, were still significant predictors of participants rating of excessive force. To examine whether specific types of sexism were responsible for the gender main effects, participant scores on the hostile sexism and benevolent sexism subscales of the ASI were entered separately into an ANCOVA. Hostile sexism did not predict rating of excessive force, $\mathrm{F}(1,513)=.089, p=.765$, partial $\eta^{2}=.00$, and adding it to the model did not significant impact the gender of the subject main effect, $\mathrm{F}(1,513)=15.015, p<.001$, partial $\eta^{2}=.03$, or the gender of the officer main effect, $\mathrm{F}(1,513)=4.769, p=.029$, partial $\eta^{2}=.01$. The addition of participant scores on the benevolent sexism subscale, $\mathrm{F}(1,513)=3.029, p=.082$, partial $\eta^{2}=.01$, did not affect the strength of the gender of the subject main effect, $\mathrm{F}(1,5143)=14.916, p<.001$, partial $\eta^{2}=.03$, or the gender of the officer main effect, $\mathrm{F}(1,513)=5.24, p=.022$, partial $\eta^{2}=.01$. However, when splitting results by participant gender, including total ASI score as a covariate made the 
gender of the officer main effect non-significant for males but not for females, F $(1,513)=4.59$, $p=.499$, partial $\eta^{2}=.002$

In a final exploration of these gender effects, participant gender was entered as an independent variable along with the profanity, gender of the officer, and gender of the subject variables. The profanity X participant gender interaction was significant, such that female participants $(M=1.77, S D=.26)$ rated use of force in arrests containing profanity as significantly more excessive than male participants $(M=1.73, S D=.24), \mathrm{F}(1,506)=4.953, p$ $=.026$, partial $\eta^{2}=.01$. The participant gender $\mathrm{X}$ gender of the officer interaction, $\mathrm{F}(1,506)=$ 5.329, $p=.021$, partial $\eta^{2}=.01$ was also significant, due to female participants $(M=1.73, S D=$ .26) rating force as more excessive when female officers were present than did male participants $(M=1.65, S D=.30)$. A three-way interaction between participant gender, gender of the subject, and gender of the officer was significant, $F(1,506)=10.13, p=.002$, partial $\eta^{2}=.02$ and these results are displayed in Figure 1. This effect was driven by female participants rating force as significantly more excessive $(M=1.74, S D=.28)$ than male participants $(M=1.52, S D=.34)$ when female officers arrested a male subject. Male participants rated force as more excessive whenever female officers arrested female subjects $(M=1.76, S D=.22)$, as did female participants $(M=1.72, S D=.24)$.

The nature of these gender differences was evident in the comments used to describe why participants rated force as they did. For those participants who found force used on a female subject to be excessive, several remarked that the officer did not need to use elevated force on a subject who was "just a girl" or "a smaller woman," that the officer was "too hard on the woman" or "too rough with the female," that "the lady did not seem to pose any danger," and one participant remarked that the officer seemed "irate when cursing at the woman and 
manhandling her was completely unnecessary." Participants who found force to be excessive when a female officer was making the arrest commented, "She was clearly having a bad day and took it out on the subject," "She should just do her job without yelling at the subject." Others remarked that the officer "seemed to get frustrated too easily," and even "she (the officer) seemed to want to make the situation worse." A few participants indicated that they felt a female officer was justified in using more force due to "being smaller than the (male) subject, "how big the subject was compared to the girl officer," and the officer having to "protect herself" and "ensure her own safety."

\section{Discussion}

This study analyzed the influence of police use of profanity on public rating of force utilizing a series of fictional arrest scenarios with police officers and subjects of either gender. Two samples (i.e., psychology undergraduate students and community adults via Amazon's Mechanical Turk survey system) were examined to determine whether there were meaningful differences between samples that might explain variance in rating of force. The student sample contained significantly more young adults (18-24 years) and more males than the community adult sample, but both samples identified as predominantly White/Caucasian. Community adults were more educated and more often married than psychology students, and more likely to live in an urban or suburban area. Greater general trust, composite trust, and specific trust in police use of force were negatively associated with rating of force as excessive, and greater exposure to online news about police behavior was positively associated with rating of force as excessive. Community adults evidenced significantly greater general trust of police than psychology students, but psychology students reported greater specific trust in police use of force. Samples did not differ significantly with regard to rating of force as excessive. 
The first aim of the study was to examine whether officer use of profanity would be associated with participant rating of force during arrest as excessive. In accordance with the first hypothesis, profanity use during arrest was associated with not only decreased quality and increased intensity of police-citizen interactions, but also participant rating of use of force as significantly more excessive than when profanity was not used. This effect was still significant after including participant gender as a covariate, which has been shown in previous research to be associated with greater sensitivity to profanity and harsh language (De Klerk, 1991; Selnow, 1985).

This finding is in line with previous research on the impact of profanity use in a professional context, such that those in a professional role who use profanity are viewed negatively (Kottke \& MacLeod, 1989; Morgan \& Korschgen, 2001; Paradise et al., 1980; Phillips \& Kassinove, 1987; Sazer, 1990), as less competent (Johnson \& Lewis, 2010), and even as being out of control (White et al., 1994) by those hearing the profanity. According to Johnson \& Lewis (2010), this could be due to "expectancy violations theory," or the notion that professionals should not use non-professional language, and when they do, the resulting "violation" is so jarring that it leads to negative impressions. The finding that profanity is also enough to tip the scale toward public rating of force as excessive is noteworthy, as it has not been documented in any other research. It is also troubling, as it suggests that if police use profanity during arrest and there is a public denigration of the force used during that arrest, it could lead to not only decreased police legitimacy and subsequent erosion to communitypolicing strategies (Brunson 2007, Gau \& Brunson, 2010), but potentially sweeping civil judgments, criminal prosecution, civil disorder, and loss of life (Skolnick \& Fyfe, 1993). 
The second aim of the study was to determine whether gender of the subject was also tied to rating of force as excessive, with the prediction that officer use of profanity in front of female subjects in particular would viewed as excessive force. This hypothesis was partially supported, in that arrests with female subjects were found to contain excessive force-but there was no significance for this main effect's interaction with profanity use. That is, arrests with female subjects were viewed as containing excessive force, regardless of whether officers used profanity. Surprisingly, this effect remained significant even after controlling for benevolent sexism, suggesting that the tendency for participants to rate force used on a woman as excessive had little to do with the idea that women are weaker than men and require additional protection.

However, previous research on assessment of gender biases suggests that when participants are made aware that gender bias is being directly examined (e.g., through the use of a face-valid measure of their attitudes about the opposite gender), they are likely to minimize said biases in favor of giving socially-desirable responses. More subtle methods of examining biased responding allow for attitudes not revealed on self-report measures to emerge through participant judgment of observed behavior. Goldberg (1968) was among the first to demonstrate this when he gave participants six articles with author gender identified by a stereotypically male or female first name (e.g., Joan or John). Participants rated articles presumably written by men more favorably and evaluated those penned by women more harshly, but only for articles in a traditionally-masculine career field. Like the participants in Goldberg (1968), it is possible that participants in this study denied benevolent sexism on the ASI, but evidenced benevolent sexism when evaluating force used on female subjects as excessive. Another potential explanation for this effect is that participants simply rated this force as excessive due to a gender-bias construct not evaluated by this study. 
The third and final aim of the study was to evaluate the effect of gender of officer with regard to rating of force and influence of profanity. This main effect was significant, illustrating that participants found arrests by female police officers to contain significantly more excessive force than those by male police officers. The initial hypothesis that officer gender would interact significantly with profanity use on rating of force as excessive was only partially supported, as female officer use of profanity was not rated as significantly more impactful than male officer use of profanity. However, female officers were rated negatively by both male and female participants, but especially by females, for their actions during arrest. Specifically, female participants were more likely to rate the force used by female officers as excessive, regardless of whether profanity was used. Male participants also rated force used by female officers as excessive, but when total score on the ASI was entered as a covariate, this effect was no longer significant. This surprising result suggests that for male participants, hostile sexism (i.e., an antagonistic attitude toward women) and/or benevolent sexism (i.e., a chivalrous attitude toward women that casts them as weak and requiring male protection) may have contributed to negative ratings of female officer use of force.

This finding is surprising and counterintuitive, as female police officers make up 12.5$17 \%$ of police in large city departments but account for only 5-9\% of excessive force complaints (Alter, 2015; Lonsway et al., 2002). Similarly-negative evaluations of female police officers have been documented in a variety of studies designed to understand the impact of recruitment of females into a predominantly male career field. Several researchers have described how female police have traditionally been viewed by their male police peers as unable to perform the rigors of the job-specifically, the tasks that might require greater physical strength or an "authoritative presence” (Balkin, 1988; Bell, 1982; Martin, 1999; Martin \& Jurik, 1996; as cited in Rabe- 
Hemp, 2008). Still others have examined how this difference may impact law enforcement operations, with older research suggesting that a female officer's inability to control violent subjects may put themselves, fellow officers, and even members of the public in danger (Belknap \& Shelley, 1992; Mishkin, 1981; Remmington, 1981). After a several-year lull in research focusing on views of female police, more recent research shows that female officers are increasingly well-accepted by not only male officers and supervisors (Archbold \& Schulz, 2008; Muftic \& Carter Collins, 2011), but also by male and female civilians (Leger, 1997; Singer \& Singer, 2001).

Despite growing acceptance of women in the field of law enforcement, and what appears to be decreased gender bias against women in general (Eagly \& Mladinic, 1989; Eagly, Mladinic, \& Otto, 1991), several theories about gender roles and/or expectations for women may explain the tendency of both women and men to rate female police officers negatively. The overall positive view of women in research, sometimes called the "women-are-wonderful effect" (as described in Eagly \& Mladinic, 1994, p. 13), is said to be the result of direct assessment of gender attitudes or gender stereotypes. However, when gender performance is evaluated indirectly or when implicit biases are targeted (see the Goldberg paradigm described above), several studies have detailed a more subtle type of negative judgment of women operating in male-dominated domains, including career fields typically represented by males-for example, STEM research and practice (Moss-Racusin, Dovidio, Brescoll, Graham, \& Handelsman, 2012; Reuben, Sapienza, \& Zingales, 2014) and leadership/business (Eagly, Makhijani, \& Klonsky (1992). This effect holds even for women in generic career fields who demonstrate more stereotypically-male behavior (Cuddy, Fiske, \& Glick, 2004; Fiske, Cuddy, \& Xu, 1999), which 
can result in "walking the tightrope," or treading the line between being seen as too feminine and incompetent, or too masculine and unlikeable (Williams, Phillips, \& Hall, 2014, p. 3).

Like the gender results in this study, effect sizes in this research were small (ranging from .12 to 32; Eagly \& Mladinic, 1994), suggesting a small tendency for women's work in traditionally-male domains to be de-valued by members of both sexes. However, biases like these could potentially contribute to a host of negative outcomes for female police, including reduced ability to promote or decreased interest in promotion (Archbold, Hassell, \& Stichman, 2010; Gaston \& Alexander, 1997; Wertsch, 1998), lack of acceptance by male officers/supervisors (Daum \& Johns, 1994; Wexler \& Logan, 1983), conflict after childbirth due to ideas of reduced work commitment or competence (Correll, Benard, \& Paik, 2007; Cuddy et al., 2004; Pogrebin, 1986; Silvestri, 2006), and low perceived confidence and self-efficacy within the law enforcement role (Martin, 1979). In one of only two international studies of attitudes toward female police (Singer \& Singer, 2001), Muftic and Carter Collins (2014) found that although the majority of Bosnian policemen felt women were just as effective as men in a police role, there were many male officers who believed that policewomen were "ineffective, problem causing, or incapable of police work" (Muftic \& Carter Collins, 2014, p. 395). Still others have described how male officers can adopt paternalistic attitudes toward their female peers, such that they attempt to protect them by removing them from dangerous events. This has the potential impact of reducing on-the-job experience, eliminating eligibility for awards or promotion, and perpetuating the notion that they are not effective officers (Martin, 1999). Male participants in this study may have also evaluated female officers negatively, perhaps due to the notion that female police appeared incompetent when interacting with an aggressive subject, or because they felt a similar obligation to "protect them" in such a situation. 
These findings have direct implications for police training, such that if police officers are directed to monitor and restrict their use of profanity and other harsh language, this could result in not only improved quality of interactions between police and the public, but also a reduction in allegations of excessive force and improvement in community policing efforts. One of the challenges of translating research into practice within the realm of police psychology is finding a way to connect police agencies to the findings that suggest that a change is in order. To ensure maximum adherence to such a policy, a training mandate addressing this change would be best disseminated by not only leaders in the field of police policy (e.g., IACP), but also by police training academies to ensure implementation early in an officer's career.

Another practical application of this research is the education of the public on what is appropriate versus excessive police use of force, as several participants in this study expressed confusion about elements of the officer's response during the fictional arrest video. For example, when the subject became verbally combative during the arrest and the officer responded with physical restraint, some participants questioned whether this was, on its own, a mismatch of force. This effect is not surprising, as public opinion regarding police UoF often differs from what police policy dictates as appropriate (Beattey \& Calkins, 2015). Procedural justice, or a process used commonly in community policing whereby officers treat members of the public fairly and with respect, requires that officers allow citizens to participate in discussions regarding their rights, explain to them why an officer is handling a dispute in a particular way, and convey genuine concern and empathy for all parties involved (Tyler, 1990, 2004; Tyler \& Huo, 2002; Mather, 2015). This method could be used to explain to individuals interacting with police why they are being questioned/detained and what level of force is appropriate given their behavior, in 
the hope that doing so will lead to not only better immediate outcomes but also more understanding of why and how police choose to use force on the job (Winter, 2016).

The strengths of this study include a large sample size, participants encompassing all ages from across the U.S., and a focus on an area considered high priority given recent eventsunprofessional police behavior. Of note, only one other team (Baseheart \& Cox, 1993) has studied police profanity directly, and no other researchers have examined the influence of profanity use on public perceptions of force. Unlike other studies of police behavior where participants completed self-report measures of their perceptions of police, this project utilized fictional arrest videos to elicit real-time judgments of appropriateness of force-perhaps eliciting a response pattern similar to how participants would respond after being presented with this information by the media. The fictional arrest scenarios were filmed using police officer staff members from a large police academy in the northeast, which could have the effect of granting a sense of technical accuracy beyond stimuli described in other studies, and the setting of the scenario (i.e., a traffic stop) represents one of the most common encounters with police. Few studies have compared samples of varying ages and experiences with regard to opinions of police behavior, and even fewer have utilized measures of police-specific attitudes documented by other researchers. This study is unique in its attempt to add to the literature by comparing younger undergraduates from a more rural locale with adults from across the U.S., and to do so by analyzing specific attitudes on police behavior, use of force, and responsiveness to the community at large.

Despite these strengths, there are some limitations that merit discussion. Study participants were told that they would be viewing an "arrest video recorded on a police car dash camera" and were not directly informed that the arrest video was fictional, so as not to impact 
results with regard to excessive force ratings. However, the pilot study results suggest that these videos could have been viewed as unrealistic or not reflective of a typical traffic stop, which could have impacted ratings of force in an unpredictable manner. For example, participants may have viewed the arrest scenario and found it to be so artificial that the use of force seemed grossly inappropriate. Given the strength of the profanity main effect, however, it is not likely that this was the case. Three of the police officer actors in the arrest videos were of average size, but one of the males was of somewhat larger build than the other. This difference in stature may have impacted participant rating of force, such that arrest videos featuring this male actor may have been associated with more frequent ratings of force as excessive. Contrary to other studies of race and interactions with police (Brunson, 2007), participant race was not associated with negative attitudes about police or greater likelihood of rating force as excessive. This could be due to the majority of participants identifying as White/Caucasian. Study participants also completed 14.11 years of education on average, which contrasts with the U.S. Census' most recent information on educational attainment that shows that approximately $59 \%$ of adults in the U.S. in 2015 reported completion of "some college or more" and 33\% completed a bachelor's degree or higher (Ryan \& Bauman, 2016). Taken together, these participant differences could affect the generalizability of these results to other, more diverse samples. Study participants did not complete a measure of social desirability, and for male participants in particular, the desire to respond in a socially-acceptable manner could explain the tendency to rate female police officers more favorably than those with greater gender biases typically would. Despite this, surveys like the one used in this study tend to minimize social desirability, as participant anonymity is assured (Elsesser \& Lever, 2011; Nederhof, 1985). The effect size for the profanity main effect in this study was very small (.10). While some may argue that this result may not have practical 
significance, the authors of this study would disagree, as even one instance of suspected police misconduct has the potential to result in high economic costs associated with hearings and legal proceedings, extensive media coverage that might impact police-community relations, and negative impact to the complainant, the police officer (who may be relieved of duty pending the investigation) and to the families of these individuals. Finally, and most notably, this data was collected in the fall of 2015, not long after the deaths of Michael Brown in Missouri, Eric Garner in New York, Treyvon Martin in Florida, and the creation of the "Black Lives Matter" movement in the U.S. The salience of these and related events in history, including national protests and associated increases in media coverage, might have influenced participants to evaluate police officers negatively in this study.

Future researchers may choose to continue to use fictional law enforcement scenarios to elicit responses tied to implicit attitudes. For example, fictional arrest videos could include interactions between officers and subjects of varying racial/ethnic groups in order to evaluate the influence of participant race or racial bias on rating of excessive force. Setting of the arrest scenario could be varied to include ones with much greater risk to the officer or increased risk of violence (e.g., a domestic violence response call) to evaluate whether participant ratings of force fluctuate with situation volatility. To further examine the nature of the gender biases examined in this sample, researchers may choose to include measures designed to tap into constructs like sex role violation, perceived efficacy of female police officers, or role congruity theory. Researchers could also choose to utilize an implicit association test (IAT) to capture gender bias for those participants likely to minimize such traits in psychological research ${ }^{3}$. Videos of arrests with varying uses of force could be used with a sample of "policy makers" (i.e., police leadership,

\footnotetext{
${ }^{3}$ Harvard University's Project Implicit@ is an often-used resource for tests of this nature and can be accessed at https://implicit.harvard.edu/implicit/takeatest.html.
} 
legislators, judges) to evaluate what those who make the final decision regarding appropriateness of force would say influences these decisions. With regard to the impact of profanity, future researchers could examine whether officer avoidance of profanity and emphasis on professional language actually does have the benefit of improving quality of police-citizen interactions such that community policing efforts are more effective.

Finally, others may choose to more directly examine the impact to female police officers of gender bias, as the results of this study suggest that due to pre-existing attitudes about their performance and role in law enforcement, outcomes could include not only negative evaluation by citizens and their male peers and fewer opportunities in law enforcement, but also potentially increased allegations of excessive force. This impact to female police officers, who have only recently begun to make their mark in the field, could prove catastrophic, so future researchers should take great care to not only better understand this phenomena, but also to investigate ways to mitigate gender bias in the workplace. 


\section{References}

Adams, K. (1995). Measuring the prevalence of police abuse of force. In: W. Geller, \& H. Toch (Eds.), And justice for all: understanding and controlling abuse of force. Washington, DC: Police Executive Research Forum.

Adams, K. (1996). Measuring the prevalence of police abuse-of-force. In Galler, W., Toch, H. (Eds). Police violence: Understanding and controlling police abuse-of-force (pp. 52-93). Yale University Press: New Haven.

Adams, K. (1999). What we know about police use of force. In: Use of force by police: overview of national and local data. Washington, DC: National Institute of Justice.

Alpert, G. P., \& Dunham, R. G. (1999, October). A research agenda on police use of force. Use of force by police: Overview of national and local data (NCJ 176330). Washington DC: U.S. Department of Justice, Bureau of Justice Statistics and National Institute of Justice.

Alpert, G., Dunham, R., \& MacDonald, J. (2004). Interactive Police-Citizen Encounters that Result in Force. Police Quarterly, 7, 475 - 488.

Alter, C. (2015, November). Why American needs more female cops. Time. Retrieved from http://time.com/4101183/why-america-needs-more-female-cops/.

Archbold, C. A., Hassell, K. D., \& Stichman, A. J. (2010). Comparing promotion aspirations among female and male police officers. International Journal of Police Science and Management, 12, 287-303. doi:10.1350/ijps.2010.12.2.175.

Archbold, C. A., \& Schulz, D. M. (2008). Making rank: The lingering effects of tokenism on female police officers' promotion aspirations. Police Quarterly, 11, 50-73. doi:10.1177/1098611107309628. 
Ariel, B., Farrar, W. A., \& Sutherland, A. (2014). The effect of police body-worn cameras on use of force and citizens' complaints against the police: A randomized controlled trial. Journal of Quantitative Criminology. doi: 10.1007/s10940-014-9236-3

Bailey, L. A., \& Timm, L. A. (1976). More on women's — and men's-expletives. Anthropological Linguistics, 18, 438-449.

Balkin, J. (1988). Why policemen don't like policewomen. Journal of Police Science and Administration, 16, 29-38.

Baudhuin, F. (1973). Obscene language and evaluative responses: An empirical study. Psychological Reports, 32, 399-402.

Baseheart, J. R., \& Cox, T. C. (1993). Effects of police use of profanity on a receiver's perceptions of credibility. Journal of Police and Criminal Psychology, 9, 9-19.

Bayard, D., \& Krishnayya, S. (2001). Gender, expletive use, and context: Male and expletive use in structured and unstructured conversation. Women and Language, 24, 1-15.

Beattey, R. A., \& Calkins, C. (2015, November). One possible path to promote police-citizen harmony. Judicial Notebook, 46, 42-43.

Belknap, J., \& Shelley, J. K. (1992). The new Lone Ranger: Policewomen on patrol. American Journal of Police, 12, 47-75.

Bell, D. J. (1982). Policewomen: Myths and realities. Journal of Police Science and Administration, 10, 29-36.

Bostrom, B. N., Baseheart, J. R. \& Rossiter, C. M. (1973). The effects of three types of profane language in persuasive messages. The Journal of Communication, 23, 461-475.

Bowers, J. S., \& Pleydell-Pearce, C. W. (2011). Swearing, euphemisms, and linguistic relativity. PLoS ONE, 6. doi:10.1371/journal.pone.0022341. 
Brandl, S. G., Stroshine, M. S., \& Frank, J. (2001). Who are the complaint prone officers? An examination of the relationship between police officers' attributes, arrest activity, assignment, and citizens' complaints about excessive force. Journal of Criminal Justice, 29, 521-529.

Brunson, R. K. (2007). “Police don’t like black people”: African-American young men’s accumulated police experiences. Criminology and Public Policy, 6, 71-102.

Brunson, R. K., \& Miller, J. (2006). Young Black men and urban policing in the United States. British Journal of Criminology, 46, 613-640. doi: 10.1093/bjc/azi093.

Buckley, K. E., \& Anderson, C. A. (2006). A theoretical model of the effects and consequences of playing video games. In P. Vorderer \& J. Bryant (Eds.). Playing video games: Motives, responses, and consequences (pp. 363-378). Mahwah, NJ: Eribaum.

Burhmester, M., Kwang, T., and Gosling, S. D. (2011). Amazon's Mechanical Turk: A New Source of Inexpensive, Yet High-Quality, Data? Perspectives on Psychological Science, 6, 3-5. doi: 10.1177/1745691610393980.

Burgoon, J. K. (1993). Interpersonal expectations, expectancy violations, and emotional communication. Journal of Language and Social Psychology, 12, 30-48. doi: $10.1177=026192 \times 93121003$

Cameron, P. (1969). Frequency and kinds of words in various social settings, or "what the hell's going on?”. Pacific Sociological Review, 12, 101-104.

Cao, L., \& Huang, B. (2000). Determinants of citizen complaints against police abuse of power. Journal of Criminal Justice. 28, 203-213. doi: 10.1016/S0047-2352(00)00036-2.

Cascio, W. F. (1977). Formal education and police officer performance. Journal of Police Science and Administration, 5, 89-96. 
Cohen, J. (1988). Statistical power analysis for the behavioral sciences (2nd ed.). Hillsdale, NJ: Erlbaum.

Cohen, B., \& Chaiken, J. M. (1972). Police background characteristics and performance: Summary. New York: Rand Institute.

Correll, S. J., Benard, S., \& Paik, I. (2007). Getting a job: Is there a motherhood penalty? American Journal of Sociology, 112, 1297-1339.

Cox, T. C., \& White, M. F. (1988). Traffic citations and student attitudes toward the police: An examination of selected interaction dynamics. Journal of Police Science and Administration, 16, 105-121.

Coyne, S. M., Stockdale, L. A., Nelson, D. A., \& Fraser, A. (2011). Profanity in media associated with attitudes and behavior regarding profanity use and aggression. Pediatrics, 128, 867-872. doi: 10.1542/peds.2011-1062.

Crank, J., \& Caldero, M. (2000). Police ethics: The corruption of noble cause. Cincinnati: Anderson Publishing.

Croft, E. B. (1985). Police use of force: An empirical analysis. State University of New York at Albany. Ann Arbor: University Microfilms.

Cuddy, A. J., Fiske, S. T., \& Glick, P. (2004). When professionals become mothers, warmth doesn't cut the ice. Journal of Social Issues, 60, 701-718.

Daum, J. M., \& Johns, C. M. (1994, September). Police work from a woman's perspective. The Police Chief, pp. 46-49.

De Klerk, V. (1991). Expletives: Men only? Communication Monographs, 58, 156-169. 
Durose, M. R., Schmitt, E. L., \& Langan, P. A. (2005). Contacts between police and the public: Findings from the 2002 national survey (Bureau of Justice Statistics). Washington DC: Government Printing Office.

Eagly, A. H., Makhijani, M. G., \& Klonsky, B. G. (1992). Gender and the evaluation of leaders: A meta-analysis. Psychological Bulletin, 111,3-22.

Eagly, A. H., \& Mladinic, A. (1989). Gender stereotypes and attitudes toward women and men. Personality and Social Psychology Bulletin, 15, 543-58.

Eagly, A. H., \& Mladinic, A. (1994). Are people prejudiced against women? Some answers from research on attitudes, gender stereotypes, and judgments of competence. European Review of Social Psychology, 5, 1-35.

Eagly, A. H., Mladinic, A., \& Otto, S. (1991). Are women evaluated more favorably than men? An analysis of attitudes, beliefs, and emotions. Psychology of Women Quarterly, 15, 20316.

Eith, C., \& Durose, M. R. (2011, October). Contacts between police and the public, 2008. Retrieved from http://www.bjs.gov/content/pub/pdf/cpp08.pdf.

Elsesser, K. M., \& Lever, J. (2011). Does gender bias against female leaders persist? Quantitative and qualitative data from a large-scale survey. Human Relations, 64, 15551578.

Fiske, S. T., Cuddy, A. J., \& Xu, J. (1999). (Dis)respecting versus (dis)liking: status and interdependence predict ambivalent stereotypes of conflict and warmth. Journal of Social Issues, 55, 473-489. 
Floyd, K., \& Voloudakis, M. (1999). Affectionate behavior in adult platonic friendships:

Interpreting and evaluating expectancy violations. Human Communication Research, 25, 341-369. doi:10.1111=j.1468-2958.1999.tb00449.x.

Friedrich, R. (1980). Police use of force: Individuals, situations, and organizations. Annals of the American Academy of Political and Social Science, 452, 82-97.

Garner, J., \& Maxwell, C. D. (1999). Measuring the amount of force used by and against the police in six jurisdictions. In Use of force by the police: overview of national and local data (pp 25-44). Washington DC: National Institute of Justice.

Garner, J. H., Maxwell, C. D., \& Heraux, C. G. (2002). Characteristics associated with the prevalence and severity of the force used by police. Justice Quarterly, 194, 705-746.

Garner, J., Buchanan, J., Schade, T., \& Hepburn, J. (1996). Understanding the use-of-force by and against the police. National Institute of Justice: Research in brief, Washington.

Gaston, K. C., \& Alexander, J. (1997). Women in the police: Factors influencing managerial advancement. Women in Management Review, 12, 47-55.

Gau, J. M., \& Brunson, R. K. (2010). Procedural justice and order maintenance policing: A study of inner-city young men's perceptions of police legitimacy. Justice Quarterly, 27, 255279.

Ginsburg, H. J., Ogletree, S. M., \& Silakowski, T. D. (2003). Vulgar language: Review of sex differences in usage, attributions, and pathologies. North American Journal of Psychology, 5, 105-116.

Glick, P., \& Fiske, S. T. (1996). Hostile and benevolent sexism: Measuring ambivalent sexist attitudes toward women. Psychology of Women Quarterly, 21, 119-135.

Goldberg, P. (1968). Are women prejudiced against women? Transaction, 5, 28-30. 
Graham v. Connor, 490 U.S. 386 (U.S., 1989).

Harris, C.J. (2010). Problem officers? Analyzing problem behavior patterns from a large cohort. Journal of Criminal Justice, 38, 216-225. doi:10.1016/j.jcrimjus.2011.05.001.

Heubusch, N., \& Horan, J. J. (1977). Some effects of counselor profanity in counseling. Journal of Counseling Psychology, 24, 456-458.

Hickman, H. (2006). Citizen complaints about police use of force. Washington, DC: Bureau of Justice Statistics.

Holmes, M. (2000). Minority threat and police brutality: Determinants of civil rights criminal complaints in U.S. municipalities. Criminology, 38, 343-368.

Holmes, M. D., \& Smith, B. W. (2012). Intergroup dynamics of extra-legal police aggression: An integrated theory of race and place. Aggression and Violent Behavior, 17, 344-353. doi:10.1016/j.avb.2012.03.006.

Holz-Ivory, A., \& Kaestle, C. E. (2013). The effects of profanity in violent video games on players' hostile expectations, aggressive thoughts and feelings, and other responses. Journal of Broadcasting and Electronic Media, 57, 224-241. doi:

10.1016/j.chb.2014.02.026.

Horton, J. J., \& Chilton, L. B. (2010, March). The labor economics of paid crowdsourcing. Proceedings of the 11th ACM Conference on Electronic Commerce, 2010. Retrieved from http://dl.acm.org/citation.cfm?id=1807376.

Howell, J. L., \& Giuliano, T. A. (2011). The effect of expletive use and team gender perceptions of coaching effectiveness. Journal of Sport Behavior, 34, 69-81. doi: 10.1016/j.avb.2012.03.006. 
Hyland, S., Langton, L. L., \& Davis, E. (2015, November). Police use of non-fatal force, 20022011. Bureau of Justice. Retrieved from http://www.bjs.gov/content/pub/pdf/punf0211.pdf.

International Association of Chiefs of Police (2015, March). The public image of police: Final report to the International Association of Chiefs of Police by the Administration of Justice Program at George Mason University. Retrieved from http://www.theiacp.org/The-Public-Image-of-the-Police.

Johnson, D., \& Lewis, N. (2010). Perceptions of swearing in the work setting: An expectancy violations theory perspective. Communication Reports, 23, 106-118. doi: 10.1080/08934215.2010.511401.

Jacobi, L. L. (2014). Perceptions of profanity: How race, gender, and expletive choice affect perceived offensiveness. North American Journal of Psychology, 16, 261-276.

Jay, T. (1992). Cursing in America: A psycholinguistic study of dirty language in the courts, in the movies, in the schoolyards and on the streets. Amsterdam Netherlands: John Benjamins Publishing Company.

Jay, T. (2000). Why we curse. Philadelphia: John Benjamins.

Jay, T. (2009). The utility and ubiquity of taboo words. Perspectives on Psychological Sciences, 4, 153-161. doi: 10.1111/j.1745-6924.2009.01115.x.

Jay, T. B., \& Janschewitz, K. (2008). The pragmatics of swearing. Journal of Politeness Research, 4, 267-288. doi:10.1515=JPLR.2008.013.

Jespersen, O. (1922). Language: Its nature, development, and origin. London: Allen \& Unwin. 
Johnson, D. I., \& Lewis, N. (2010). Perceptions of swearing in the work setting: An expectancy violations theory perspective. Communication Reports, 23, 106-118. doi:10.1080/08934215.2010.511401.

Kaminski, R. J., DiGiovanni, C., \& Downs, R. (2003). The use of force between the police and persons with impaired judgment. Police Quarterly, 7, 311-318.

Kaye, B. K., \& Sapolsky, B. S. (2009). Taboo or not taboo? That is the question: Offensive language on prime-time broadcast and cable programming. Journal of Broadcasting and Electronic Media, 53, 22-37. doi:10.1080=08838150802643522.

Klockars, C. B. (1996) A theory of excessive force and its control. In W. A. Geller \& H. Toch (Eds.) Police violence: Understanding and controlling police abuse of force (pp. 1-22). New Haven, CT: Yale University Press.

Kottke, J. L., \& MacLeod, C. D. (1989). Use of profanity in the counseling interview. Psychological Reports, 65, 627-634.

Kramer, C. (1975). Women's speech: Separate but unequal? In B. Thorne \& N. Henley (Eds.) Language and Sex: Difference and dominance. Rowley, MA: Newbury House.

Lai, Zhao, \& Jihong (2010). The impact of race/ethnicity, neighborhood context, and police/citizen interaction on residents' attitudes toward the police. Journal of Criminal Justice, 38(4), 685-692. doi: 10.1016/j.jcrimjus.2010.04.042.

Lakoff, R. (1973). Language and women's place. Language in Society, 2, 45-80.

Langan, P. A., Greenfield, L. A., Smith, S. K., Durose, M. R., \& Levin, D. J. (2001, February). Contacts between police and the public: Findings from the 1999 national survey (NCJ 184957). Washington, DC: U.S. Department of Justice, Bureau of Justice Statistics and National Institute of Justice. 
LaPointe, L. L. (2006). Profanity. Journal of Medical Speech-Language Pathology, 14(1), vii-ix.

Leger, K. (1997). Public perceptions of female police officers on patrol. American Journal of Criminal Justice, 21, 231-250.

Lonsway, K., Wood, M., Fickling, M., De Leon, A., Moore,, M.... \& Spillar, K. (2002, April). Men, women, and police excessive force: A tale of two genders. National Center for Women \& Policing. Retrieved from http://womenandpolicing.com/PDF/2002_Excessive_Force.pdf.

Mabry, E. (1974). Dimensions of profanity. Psychological Reports, 35, 387-391.

Martin, S. E. (1979). Policewomen and policewomen: Occupational role dilemmas and choices of female officers. Journal of Police Science and Administration, 7, 314-323.

Martin, S. (1999). Police force or police service? Gender and emotional labor. Annals of the American Academy of Political and Social Science, 561, 111-126.

Martin, S., \& Jurik, N. (1996). Doing justice, doing gender. Thousand Oaks, CA: Sage.

Mather, K. (2015, August). LAPD urges officers to be community guardians, not warriors on crime. Los Angeles Times. Retrieved from http://www.latimes.com/local/crime/la-mewarrior-guardians-20150821-story.html.

McElvain, J. P., \& Kposowa, A. J. (2004). Police officer characteristics and internal affairs investigations for use of force allegations. Journal of Criminal Justice, 32, 265-279. doi:10.1016/j.jcrimjus.2004.02.006.

McEnery, T. (2006). Swearing in English. New York: Routledge

Mehl, M., \& Pennebaker, J. (2003). The sounds of social life: A psychometric analysis of student's daily social environments and natural conversations. Journal of Personality and Social Psychology, 84, 857-870. 
Mehl, M., Gosling, S., \& Pennebaker, J. (2006). Personality in its natural habitat: Manifestations and implicit folk theories of personality in daily life. Journal of Personality and Social Psychology, 90, 862-877.

Micucci, A. J., \& Gomme, I. M. (2005). American police and subcultural support for the use of excessive force. Journal of Criminal Justice, 33, 487-500.

Mishkin, B. D. (1981). Female police in the United States. Police Journal, 54, 22-33.

Morgan, B. L., \& Korschgen, A. J. (2001). College Student Journal, 35, 418-432.

Moss-Racusin, C. A., Dovidio, J. F., Brescoll, V. L., Graham, M. J., \& Handelsman, J. (2012). Science faculty's subtle gender biases favor male students. Proceedings of the National Academy of Sciences, 109, 16474-16479.

Muftic, L. R., \& Carter Collins, S. (2014). Gender attitudes and the police in Bosnia and Herzegovina: male officers' attitudes regarding their female counterparts. Police Practice and Research, 15, 389-403.

Mulac, A. (1976). Effects of obscene language upon three dimensions of listener attitudes. Communication Monographs, 43, 300-307.

Nederhof, A. J. (1985). Methods of coping with social desirability bias: A review. European Journal of Social Psychology, 15, 263-280.

Nerbonne, G. P., Hipskind, N. M. (1972). The use of profanity in conversational speech. Journal of Communication Disorders, 5, 47-50.

Paletz, D., \& Haris, W. F. (1975). Four-letter threats to authority. Journal of Politics, 37, 955979. 
Paradise, L. V., Cohl, B., \& Zweig, J. (1980). Effects of profane language and physical attractiveness on perceptions of counselor behavior. Journal of Counseling Psychology, 27, 620-624.

Pate, A., \& Fridell, L. (1993). Police use of force: Official reports, citizen complaints, and legal consequences. Washington DC: Police Foundation.

Patrick, G. T. W. (1901). The psychology of profanity. Psychological Review, 8, 113-127.

Perez, D. W. (1994). Common sense about police review. Philadelphia, PA: Temple University Press.

Phillips, S. W. (2010). Police officers' opinions of the use of unnecessary force by other officers. Police Practice and Research, 11, 197-210. doi: 10.1080/15614260902830054.

Phillips, M., \& Kassinove, H. (1987). Effects of profanity, touch, and sex of the counselor on perceptions of the counselor and behavioral compliance: Implications for rationalemotive therapists. Journal of Rational Emotive Therapy, 5, 3-12.

Pogrebin, M. (1986). The changing role of women: Female police officers' occupational problems. Police-Journal, 59, 127-133.

Powell, L., Callahan, K., Comans, C., McDonald, L., Mansell, J...\& Williams, V. (1984). Offensive language and impressions during an interview. Psychological Reports, 55, 617618.

President's Task Force on $21^{\text {st }}$ Century Policing (2015, March). Interim Report of the President's Task Force on 21st Century Policing. Washington, DC: Office of Community Oriented Policing Services.

Rabe-Hemp, C. E. (2008). Female officers and the ethic of care: Does officer gender impact police behaviors? Journal of Criminal Justice, 36, 426-434. 
Rasmussen, J. L., \& Moely, B. E. (1986). Impression formation as a function of the sex role appropriateness of linguistic behavior. Sex Roles, 14(3/4), 149-161.

Rassin, E., \& Muris, P. (2005). Why do women swear? An exploration of reasons for and perceived efficacy of swearing in Dutch female students. Personality and Individual Differences, 38, 1669-1674. doi:10.1016=j.paid.2004.09.022.

Rassin, E., \& Van der Heiden, S. (2005). Appearing credible? Swearing helps! Psychology, Crime, \& Law, 11, 177-182. doi:10.1080=106831605160512331329952.

Remmington, P. W. (1981). Policing: The occupation and introduction of female police officers. Washington, DC: University Press of America.

Reuben, E., Sapienza, P., \& Zingales, L. (2014). How stereotypes impair women's careers in science. Proceedings of the National Academy of Sciences of the United States, 111, 4403-4408.

Robinson, J. (2011). The IACP use-of-force continuum. Retrieved from http://www.ehow.com/facts_7214778_iacp-use-of-force-continuum.html.

Rosenbaum, D. P., Schuck, A. M., Costello, S. K., Hawkins, D. F., \& Ring, M. K. (2005). Attitudes toward the police: The effects of direct and vicarious experience. Police Quarterly, 8, 343-365. doi:10.1177/1098611104271085.

Rossiter, C. M., \& Bostrom, R. N. (1969). Profanity, justification, and source credibility. Paper presented at the annual conference of the National Society for the Study of Communication.

Rothwell, J. D. (1971). Verbal obscenity: Time for second thoughts. Journal of Western Speech, 35, 231-242. 
Ryan, C. L. \& Bauman, K. (2016, March). Educational attainment in the United States: 2015. United States Census Bureau. Retrieved from https://www.census.gov/content/dam/Census/library/publications/2016/demo/p20578.pdf

Sazer, L. (1990). Effects of profanity, religiosity, and gender on acquisition of psychotherapy lecture content and behavioral compliance. Dissertation Abstracts International, 50, 3176B.

Scheffer, J. (2002). Dealing with missing data. Res. Mathematic and Information Science Letters, 3, 153-160

Scherer, C. R., \& Sagarin, B. J. (2006). Indecent influence: The positive effects of obscenity on persuasion. Social Influence, 1, 138-146. doi: 10.1080/15534510600747597.

Schuck, A. (2004). The masking of racial and ethnic disparity in police use of physical force: The effects of gender and custody status. Journal of Criminal Justice, 32, 557 564.

Selnow, G. W. (1985). Sex differences in the uses and perceptions of profanities. Sex Roles, 12(3/4), 303-312.

Silvestri, M. (2006). Doing time: Becoming a police leader. International Journal of Police Science and Management, 8, 266-281.

Singer, M. S., Singer, A. E. (2001). Sex differences in the perception of male and female police officers in New Zealand. The Journal of Psychology, 119, 53-57.

Skogan, W. G., \& Hartnett, S. M. (1997). Community policing, Chicago style. New York: Oxford University Press. 
Skolnick, J. H., \& Fyfe, J. J. (1993). Above the law: police and the excessive use-of-force. Free Press: New York.

Sona Systems, Ltd. (2014). Sona Systems Brochure. Retrieved from http://www.sonasystems.com/research-management.aspx.

Staley, C. M. (1978). Male-female use of expletives: A heck of a difference in expectations. Anthropological Linguistics, 20, 367-380.

Stephens, R., \& Umland, C. (2011). Swearing as a response to pain: Effect of daily swearing frequency. The Journal of Pain, 12, 1274-1281. doi: 10.1016/j.jpain.2011.09.004.

Subrahmanyam, K., Smahel, D., \& Greenfield, P. (2006). Connecting developmental constructions on the internet: Identity presentation and sexual exploration in online teen chat rooms. Developmental Psychology, 42, 395-406.

Tabachnick, B. G., \& Fidell, L. S. (2007). Using multivariate statistics. Boston, MA: Pearson.

Terrill, W., \& Mastrofski, S. D. (2002). Situational and officer-based determinants of police coercion. Justice Quarterly, 192, 215-248.

Terrill, W., \& McCluskey, J. (2002). Citizen complaints and problem officers: Examining officer behavior. Journal of Criminal Justice, 30, 143-155.

Terrill, W., Paoline, E. A., \& Manning, P. K. (2003). Police culture and coercion. Criminology, 414, 1003-1034.

Thelwall, M. (2008). Fk yea I swear: Cursing and gender in a corpus of MySpace pages. Corpora, 3, 83-107.

Toch, H. (1995). The "violence-prone" police officer. In W. Geller \& H. Toch (Eds.), And justice for all: Understanding and controlling police abuse of force. Washington, DC: Police Executive Research Forum. 
Tyler, T. R. (1990). Why people obey the law: Procedural justice, legitimacy, and compliance. New Haven, CT: Yale University Press.

Tyler, T. R. (2004). Enhancing police legitimacy. The Annals of the American Academy of Political and Social Science, 593, 84-99.

Tyler, T. R. and Huo, Y. J. (2002). Trust in the law: Encouraging public cooperation with the police and courts. New York: Russell Sage Foundation.

U. S. Census Bureau. (2013). Race - About. Retrieved from http://www.census.gov/topics/population/race/about.html.

Vingerhoets, J. J. M., Bylsma, L. M., \& de Vlam, C. (2013). Swearing: A biopsychosocial perspective. Psychological Topics, 22, 287-304.

Vincze, L. (1985). Hungarian peasant obscenity: Sociolinguistic implications. Ethnology, 24, 3342.

Wagner, A. E. (1980). Citizen complaints against the police: The complainant. Journal of Police Science and Administration. 8, 373-377.

Warshay, D. W., \& Warshay, L. H. (1978). Obscenity and male hegemony. Paper presented at the ISA Meetings.

Wertsch, T. L. (1998). Walking the thin, blue line: policewomen and Tokenism today. Women and Criminal Justice, 9, 23-61.

Wexler, J. G., \& Logan, D. D. (1983). Sources of stress among women police officers. Journal of Police Science and Administration, 11, 46-53.

White, R. (2002). Indigenous young Australians, criminal justice and offensive language. Journal of Youth Studies, 5, 21-34. doi: 10.1080/13676260120111742. 
White, M. F., Cox, T. C., \& Baseheart, J. (1988, April). Perceptions of police verbal abuse as an influence on respondent attitudes toward the police. Paper presented at the Annual Meeting of the Academy of Criminal Justice Sciences, San Francisco, CA.

White, M. F., Cox, T. C., \& Baseheart, J. (1994). Theoretical considerations of officer profanity and obscenity in formal contacts with citizens. In T. Barker and D. L. Carter (Eds.), Police Deviance (pp. 224-245). Cincinnati: Anderson.

Wiley, D. A., \& Locke, D. C. (1982). Profanity as a critical variable in counseling. Counselor Education and Supervision, 21, 245-252.

Williams, J. C., Phillips, K. W., \& Hall, E. V. (2014) Double jeopardy? Gender bias against women of color in science. Retrieved from http://www.uchastings.edu/news/articles/2015/01/double-jeopardy-report.pdf.

Winter, R. J. (2016, February). Black lives matter: Psychological research findings offer ways to foster justice. Judicial Notebook, 47. Retrieved from http://www.apa.org/monitor/2016/02/jn.aspx.

Wolfe, J. C. (1992). Sex, violence, and profanity: Rap music and the first amendment. Mercer L. Rev, 44, 667.

Worden, R. (1995). The causes of police brutality: Theory and evidence on police use of force. In W. Geller \& H. Toch (Eds.) And justice for all: Understanding and controlling police abuse and force (pp. 31-60). Washington DC: Police Executive Research Forum.

Zar, J. H. (1996). Biostatistical Analysis. Upper Saddle River, NJ: Prentice-Hall.

Zimmerman, D. \& West, C. (1979). Sex roles, interruptions and silences in conversation. In B. Thorne \& N. Henly (Eds.) Language and sex difference and dominance (pp. 105-129). Rowley, MA: Newberry House. 
Table 1

Comparison of demographic characteristics of students versus community adults.

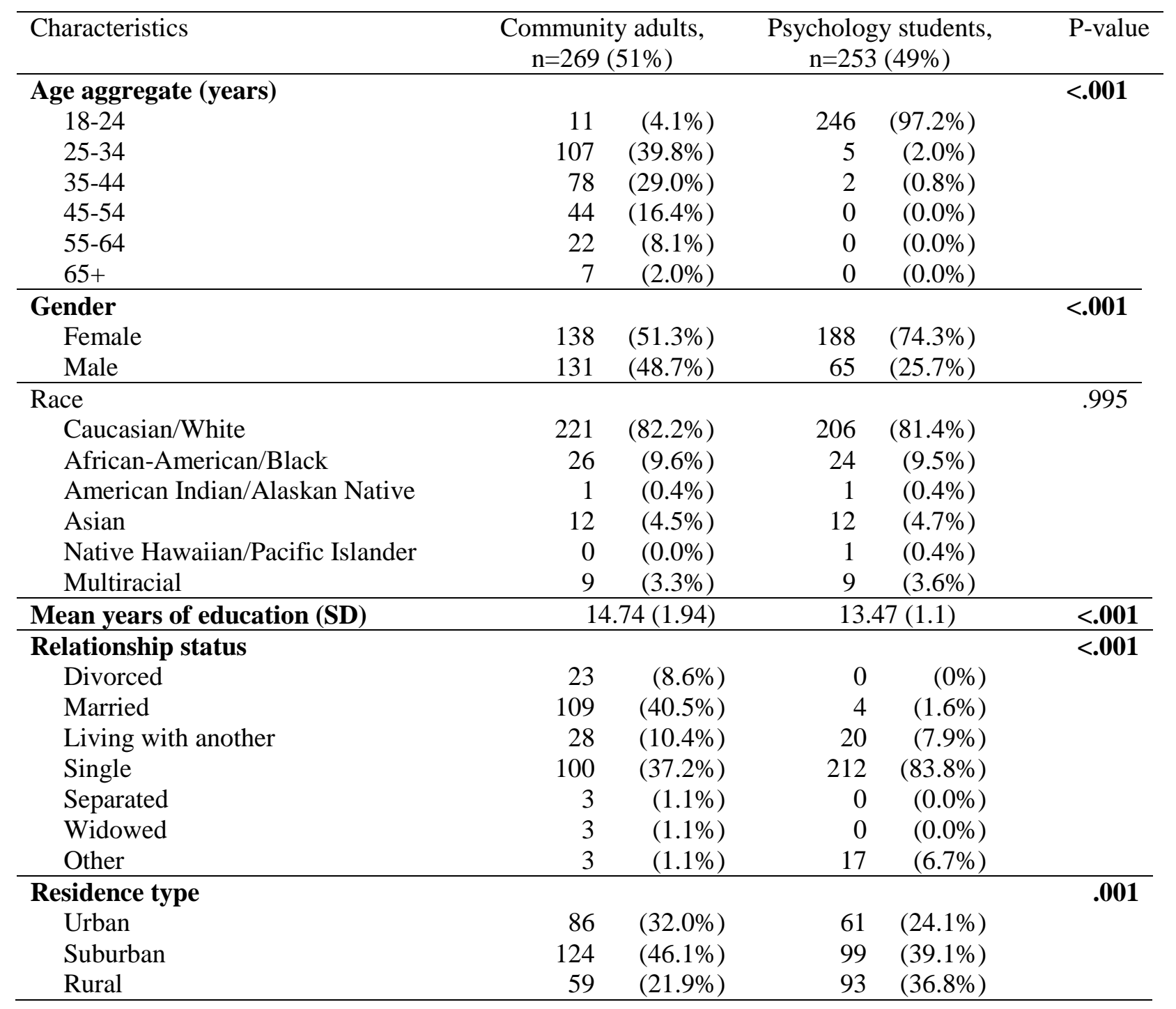

Note. Variables in bold were identified to be significantly different from one another during chi-square analysis. Mean years of education for participants was compared using an independent $t$-test. 
Table 2

Bivariate correlations between exposure to police variables, trust in police, and ratings of excessive force.

\begin{tabular}{|c|c|c|c|c|c|c|c|c|c|c|c|c|}
\hline & & 1 & 2 & 3 & 4 & 5 & 6 & 7 & 8 & 9 & 10 & 11 \\
\hline 1 & Rating of force as excessive & 1 & & & & & & & & & & \\
\hline 2 & General Trust in Police & $-.126^{* *}$ & 1 & & & & & & & & & \\
\hline 3 & Composite Trust in Police & $-.142 * *$ & $.150 * *$ & 1 & & & & & & & & \\
\hline 4 & Specific Trust in Police UoF & $-.161 * *$ & $.273 * *$ & $.554 * *$ & 1 & & & & & & & \\
\hline 5 & Reading news about police & -.003 & .021 & .010 & -.063 & 1 & & & & & & \\
\hline 6 & Viewing police news/media online & -.033 & .031 & -.021 & $-.110^{*}$ & $.592 * *$ & 1 & & & & & \\
\hline 7 & Know someone arrested by police & .001 & -.077 & $-.130 * *$ & $-.094 *$ & $.180 * *$ & $.117 * *$ & 1 & & & & \\
\hline 8 & Ever been arrested by police & .045 & .068 & $-.197 * *$ & $-.181 * *$ & -.005 & .065 & $.151^{* *}$ & 1 & & & \\
\hline 9 & Friends working in law enforcement & -.035 & -.035 & $.088 *$ & $.148 * *$ & $.153 * *$ & $.096^{*}$ & $.211 * *$ & -.021 & 1 & & \\
\hline 10 & Family working in law enforcement & -.055 & -.011 & $.104^{*}$ & .082 & $.107 *$ & .052 & $.119 * *$ & -.024 & $.264 * *$ & 1 & \\
\hline 11 & ASI total score & .094 & .026 & -.018 & $.150^{*}$ & .014 & -.064 & .073 & .058 & .104 & .068 & 1 \\
\hline
\end{tabular}

Note. $* *$ Correlation is significant at the .01 level (2-tailed). * Correlation is significant at the .05 level (2-tailed). General Trust, Composite Trust, and Specific Trust variables comprised of total scores on those measures of trust of police. ASI = Ambivalent Sexism Inventory; UoF = Use of Force. 
Table 3

Previous exposure to police.

\begin{tabular}{lrrrrr}
\hline Type of exposure & \multicolumn{2}{c}{$\begin{array}{c}\text { Community } \\
\text { adults, }\end{array}$} & \multicolumn{2}{c}{$\begin{array}{c}\text { Psychology } \\
\text { students, }\end{array}$} & P-value \\
& $\mathrm{n}=269(51 \%)$ & $\mathrm{n}=253(49 \%)$ & \\
\hline Any family members in law enforcement & $\mathbf{2 2}$ & $\mathbf{( 8 . 2 \% )}$ & $\mathbf{6 4}$ & $\mathbf{( 2 5 . 3 \% )}$ & $<.001$ \\
Any friends in law enforcement & $\mathbf{3 8}$ & $(\mathbf{1 4 . 1 \%})$ & $\mathbf{1 0 8}$ & $\mathbf{( 4 2 . 7 \% )}$ & $<.001$ \\
Ever arrested & $\mathbf{5 2}$ & $\mathbf{( 1 9 . 3 \% )}$ & $\mathbf{1 1}$ & $\mathbf{( 4 . 3 \% )}$ & $<.001$ \\
Know someone previously arrested & $\mathbf{1 9 1}$ & $\mathbf{( 7 1 . 0 \% )}$ & $\mathbf{2 1 9}$ & $\mathbf{( 8 6 . 6 \% )}$ & $<.001$ \\
Often read news stories about police & $\mathbf{2 0 2}$ & $\mathbf{( 7 5 . 1 \% )}$ & $\mathbf{2 1 5}$ & $\mathbf{( 8 5 . 0 \% )}$ & $\mathbf{. 0 0 5}$ \\
Often view stories about police online & $\mathbf{2 1 6}$ & $(\mathbf{8 4 \%})$ & $\mathbf{2 2 3}$ & $\mathbf{( 9 9 . 1 \% )}$ & $\mathbf{. 0 1 4}$ \\
\hline
\end{tabular}

Note. Variables in bold were identified to be significantly different from one another using independent samples t-tests. 


\section{Table 4}

Impact of attitudes about police and specific trust of police use of force on rating of excessive force.

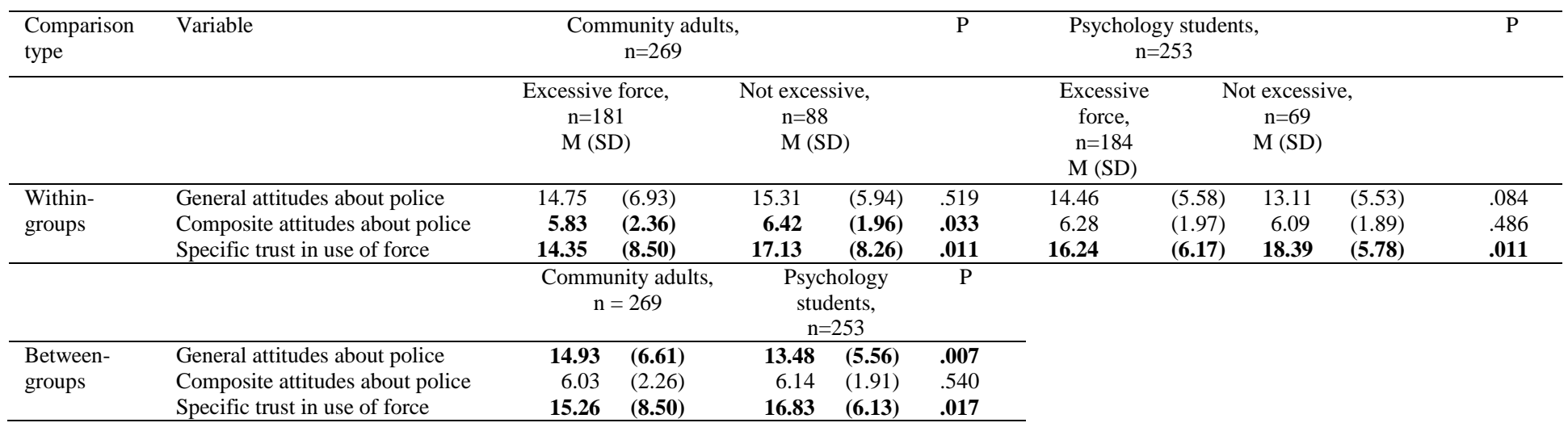

Note. Within-group comparisons analyzed the difference between each sample (e.g., community adults who rated force as excessive were compared to community adults who did not find force excessive). Between-group comparisons analyzed the difference between samples (e.g., community adult general attitudes about police were compared to psychology student general attitudes about police). Excessive and not excessive force groups were compared for each sample using an independent samples t-test. Variables in bold were identified to be significantly different from one another within each sample (within-groups) and between each sample (between-groups). Lower scores reflect less positive attitudes about police and less trust of police use of force during arrest. Participant rating of force determined using dichotomous use of force variable (i.e., "Overall, would you rate the level of force used as excessive?” Yes/No). Levene's test for violation of homogeneity of variance assumption was non-significant for all variables. 
Table 5

Analysis of Variance (ANOVA) between profanity, gender of officer, and gender of subject independent variables.

\begin{tabular}{lrrrr}
\hline & $d f$ & $F$ & $p$ & partial $\eta^{2}$ \\
\hline Profanity & $\mathbf{1}$ & $\mathbf{5 7 . 1 4}$ & $<.001$ & $\mathbf{. 0}$ \\
Gender of officer & $\mathbf{1}$ & $\mathbf{4 . 7 3}$ & $\mathbf{. 0 3 0}$ & $\mathbf{. 0 1}$ \\
Gender of subject & $\mathbf{1}$ & $\mathbf{1 4 . 9 9}$ & $<.001$ & $\mathbf{. 0 3}$ \\
Profanity X Gender of officer & 1 & 1.91 & .168 & $<.01$ \\
Profanity X Gender of subject & 1 & .74 & .391 & $<.01$ \\
Gender of officer X Gender of subject & 1 & .26 & .610 & $<.01$ \\
Profanity X Gender of officer X Gender of subject & 1 & .51 & .476 & $<.01$ \\
\hline
\end{tabular}

Note. $N=522$. Significant effects bolded for emphasis. 
Table 6

Analysis of Co-Variance (ANCOVA) between main study independent variables (profanity, gender of officer, and gender of subject) and covariates (General Trust, Composite Trust, Specific Trust in UoF, ASI total score, Benevolent Sexism, and Hostile Sexism).

\begin{tabular}{lrrrr}
\hline & $d f$ & $F$ & $p$ & partial $\eta^{2}$ \\
\hline Profanity & $\mathbf{1}$ & $\mathbf{5 2 . 9 0}$ & $<.001$ & $\mathbf{. 0 9}$ \\
Gender of officer & $\mathbf{1}$ & $\mathbf{6 . 0 0}$ & $\mathbf{. 0 1 5}$ & $\mathbf{. 0 1}$ \\
Gender of subject & $\mathbf{1}$ & $\mathbf{1 5 . 5 8}$ & $<.001$ & $\mathbf{. 0 3}$ \\
Profanity X Gender of officer & 1 & 2.81 & .094 & .01 \\
Profanity X Gender of subject & 1 & 1.04 & .308 & $<.01$ \\
Gender of officer X Gender of subject & 1 & 1.50 & .699 & $<.01$ \\
Profanity X Gender of officer X Gender of subject & 1 & .64 & .424 & $<.01$ \\
General Trust in Police & 1 & 3.20 & .074 & .01 \\
Composite Trust in Police & 1 & .54 & .462 & $<.01$ \\
Specific Trust in Police UoF & $\mathbf{1}$ & $\mathbf{5 . 5 8}$ & $\mathbf{. 0 1 9}$ & $\mathbf{. 0 1}$ \\
ASI total score & 1 & 1.41 & .235 & $<.01$ \\
Benevolent Sexism & 1 & 3.03 & .082 & .01 \\
Hostile Sexism & 1 & .09 & .765 & $<.01$ \\
\hline
\end{tabular}

Note. $N=522$. Significant effects bolded for emphasis. Dependent variable $=$ participating rating of force as excessive. $\mathrm{UoF}=$ Use of Force, ASI = Ambivalent Sexism Inventory. 
Figure 1

Interaction of participant gender, gender of the subject, and gender of the officer independent variables.
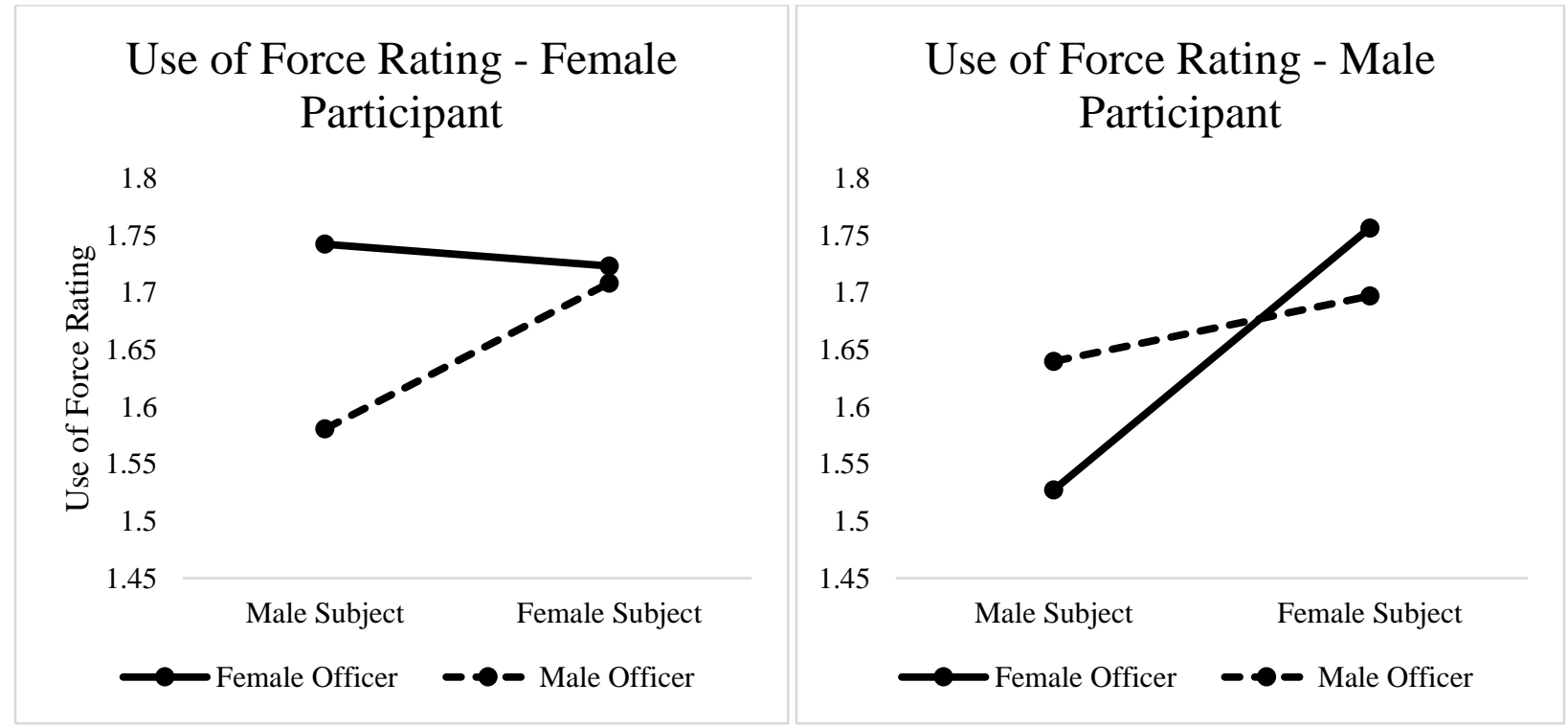

Note. Use of force rating evaluated using 1-4 Likert scale item, "Please rate the appropriateness of the level of force used during the arrest," with $1=$ not at all excessive and $4=$ very excessive. This variable was analyzed using a square root transformation to reduce violations of normality, so current values are different from original scale (i.e., 1-4). 
Appendix A

\section{SCRIPT A - NO PROFANITY}

\section{$\underline{\text { Main Scene }}$}

OPENING - BLACK SCREEN - Audio dialogue begins of communication between police dispatcher and patrol vehicle. While dialogue plays, what is said appears in text on screen:

\section{DISPATCHER:}

“County to Car 16?”

OFFICER:

“16."

\section{DISPATCHER:}

“That's a confirm - subject has an active bench warrant out of Smith County. Will you be transporting?"

OFFICER:

“10-4, Stand-by."

\section{TEXT FADES OUT}

EXTERIOR - ROADSIDE SHOULDER - DAYLIGHT

OFFICER AND VIOLATOR ARE STANDING AT THE REAR OF THE VIOLATOR'S VEHICLE AND IN FRONT OF THE POLICE VEHICLE. VIOLATOR IS STANDING AT THE REAR CENTER FACING THE VEHICLE WITH HANDS ON THE TRUNK. OFFICER IS STANDING TO THE LEFT (DRIVER'S SIDE).

\section{VIOLATOR:}

(Turning toward the Officer) “Officer, what's going on?”

\section{OFFICER:}

"I pulled you over and you have an outstanding warrant. Now put your hands on the car."

\section{VIOLATOR:}

"No way. Are you kidding? No way, man." 


\section{OFFICER:}

"I said-keep your hands on the car." (Moving toward the Violator) "There's a bench warrant for your arrest. I need you to put your hands behind your back right now." (Begins to reach for handcuffs)

\section{VIOLATOR:}

(Turns toward Officer a second time with hands raised above waist) “Wait, what? C'mon!”

\section{OFFICER:}

“TURN AROUND AND PUT YOUR HANDS BEHIND YOUR BACK. YOU'RE UNDER ARREST!'”(Officer grabs Violator's right arm and attempts to turn the Violator's body back toward the rear of the Violator's vehicle)

\section{VIOLATOR:}

(Violator bends and raises the right arm, beginning to resist) “No, wait...I can explain! Stop it!" OFFICER USES AN ARMBAR TECHNIQUE TO DRIVE THE VIOLATOR FORWARD AND DOWN INTO THE TRUNK OF THE VEHICLE WITH A LOUD 'BANG'.

\section{OFFICER:}

“Get on the ground!"

OFFICER THEN SPINS THE VIOLATOR TO THE GROUND, MOVING THE VIOLATOR'S ARM TO THE SMALL OF THE BACK. VIOLATOR IS FACE DOWN WITH OFFICER KNEELING OVER TOP. OFFICER REACHES FOR AND BEGINS TO HANDCUFF THE VIOLATOR. SAYS:

“Stay down - stop resisting - do you understand?"

FADE OUT 


\section{SCRIPT B - PROFANITY}

Using the above scene, the "voice over" will contain the following dialogue:

VIOLATOR:

“Officer, what's going on?”

OFFICER:

"I pulled you over and you have an outstanding warrant. Now put your hands on the car."

\section{VIOLATOR:}

"No way. Are you kidding? No way, man."

\section{OFFICER:}

“I said-keep your Fuckin' hands on the car. There's a bench warrant for your arrest. I need you to put your Fuckin' hands behind your back right now."

VIOLATOR:

“Wait, what? C'mon”

OFFICER:

“TURN AROUND AND PUT YOUR FUCKIN' HANDS BEHIND YOUR BACK! YOU'RE UNDER ARREST!"

VIOLATOR:

“No, wait...I can explain! Stop it!”

OFFICER:

“GET ON THE FUCKING GROUND!”

OFFICER THEN SPINS THE VIOLATOR TO THE GROUND, MOVING THE VIOLATOR'S ARM TO THE SMALL OF THE BACK. VIOLATOR IS FACE DOWN WITH OFFICER KNEELING OVER TOP. OFFICER REACHES FOR AND BEGINS TO HANDCUFF THE VIOLATOR. SAYS:

"Stay down - stop resisting!” 
PAUSES, THEN EXHAUSTEDLY UNDER THE BREATH: “WHAT THE FUCK...”

FADE OUT 
Appendix B

\section{Standard Demographic Questionnaire}

1. What is your age?

1. $18-24$

2. $25-34$

3. $35-44$

4. $45-54$

5. $65+$ years

2. What is your gender?

1. Male

2. Female

3. How would you classify yourself?

1. Caucasian/White

2. Black/African-American

3. American Indian/Alaskan Native

4. Asian

5. Native Hawaiian or Other Pacific Islander

6. Multiracial

4. How many years of education do you have? (Open response)

5. What is your current relationship status?

1. Divorced

2. Married

3. Living with another

4. Single

5. Separated

6. Widowed

7. Other

6. What is your occupation? (Open response)

7. What is your home state? (Drop-down of all states)

8. Do you live in an urban, rural, or suburban place?

1. Urban 
2. Rural

3. Suburban 


\section{Exposure to Police}

1. Do any of your family members work in in law enforcement?

1. Yes

2. No

2. Do any of your friends work in law enforcement?

1. Yes

2. No

3. Have you ever been arrested by a law enforcement officer?

1. Yes

2. No

4. Do you know someone who was previously arrested by a law enforcement officer?

1. Yes

2. No

5. Do you often read stories about police and/or police actions on the news?

1. Yes

2. No

6. Do you often view news stories about police and/or police actions on television or on the internet?

1. Yes

2. No 


\section{$\underline{\text { Trust and Confidence in Police Scale - Short Version }}$}

Adapted from:

Rosenbaum, D. P., M., Costello, S. K., Hawkins, D. F., \& Ring, M. K. (2005). Attitudes toward the police: The effects of direct and vicarious experience. Police Quarterly, 8, 343-265. doi: $10.1177 / 1098611104271085$

\section{A. General Attitudes About Police}

Here are a few questions about police officers in general. For each one, please indicate if you strongly agree, somewhat agree, somewhat disagree, or strongly disagree.

Q1. Police officers are decent, law-abiding people. Do you...

$<1>\quad$ Strongly agree

$<2\rangle$ Somewhat agree

$<3>\quad$ Somewhat disagree

$<4 \quad$ Strongly disagree

Q2R. Police officers are often rude to the public. Do you...

$<1>\quad$ Strongly agree

$<2>\quad$ Somewhat agree

$<3>\quad$ Somewhat disagree

$<4>\quad$ Strongly disagree

Q3. Police officers are fair and just when enforcing the law. Do you...

$<1>\quad$ Strongly agree

$<2>\quad$ Somewhat agree

$<3>\quad$ Somewhat disagree

$<4>\quad$ Strongly disagree

Q4R. Police officers stop people for no good reason. Do you...

Strongly agree

Somewhat agree

Somewhat disagree

Strongly disagree

Q5. Police officers treat all people equally regardless of their race. Do you...

$<1>\quad$ Strongly agree

$<2>$ Somewhat agree 
$<3>\quad$ Somewhat disagree

$<4>\quad$ Strongly disagree

Q6R. Police officers do not treat young people with respect. Do you...

$<1>\quad$ Strongly agree

$<2>\quad$ Somewhat agree

$<3>\quad$ Somewhat disagree

$<4>\quad$ Strongly disagree

Q7R. Police officers are more interested in making arrests than in seeking the truth. Do you...

$<1>\quad$ Strongly agree

$<2>\quad$ Somewhat agree

$<3>\quad$ Somewhat disagree

$<4>\quad$ Strongly disagree

Q8R. Police officers are corrupt. Do you...

$<1>\quad$ Strongly agree

$<2>\quad$ Somewhat agree

$<3>\quad$ Somewhat disagree

$<4>\quad$ Strongly disagree

Q9R. Police officers are physically abusive to people. Do you...
$<1>\quad$ Strongly agree
$<2>\quad$ Somewhat agree
$<3>\quad$ Somewhat disagree
<4> Strongly disagree

Q10R. Police officers are verbally abusive to people. Do you...
$<1>\quad$ Strongly agree
$<2>\quad$ Somewhat agree
$<3\rangle \quad$ Somewhat disagree
$<4>\quad$ Strongly disagree

Q11. Police officers are held accountable and disciplined when they do something wrong. Do you...

$<1>\quad$ Strongly agree

$<2>\quad$ Somewhat agree

$<3>\quad$ Somewhat disagree

$<4 \quad$ Strongly disagree 


\section{B. Composite Measure of Attitudes Toward the Police (using 3 items from Skogan \&}

Hartnett, 1997)

** Now let's talk specifically about police in your neighborhood.

Q12. How responsive are the police in your neighborhood to your community concerns? Do you think they are...

$<1>\quad$ Very responsive

$<2>$ Somewhat responsive

$<3>\quad$ Somewhat un-responsive

$<4>\quad$ Very un-responsive

Q13. How good a job do you think the police are doing to prevent crime in your neighborhood? Would you say they are doing a...

$<1>\quad$ Very good job

$<2>\quad$ Good job

$<3>\quad$ Fair job

$<4>\quad$ Poor job

Q14. In general, how polite are the police when dealing with people in your neighborhood? Are they...

$<1>\quad$ Very polite

$<2>\quad$ Somewhat polite

$<3>\quad$ Somewhat impolite

$<4>\quad$ Very impolite

Scoring: All items summed. Items marked with an "R" are reverse scored. Higher scores indicate less trust and/or satisfaction in/with police. 


\section{Specific Trust in Police Scale - Use of Force Adaptation}

Adapted from:

Lai, Yung-Lien, \& Zhao, Jihong Solomon. (2010). The impact of race/ethnicity, neighborhood context, and police/citizen interaction on residents' attitudes toward the police. Journal of Criminal Justice, 38(4), 685-692. doi: 10.1016/j.jcrimjus.2010.04.042.

Please answer the following questions about your local police department. For the questions asking about use of force during an arrest, "excessive force" is defined as "more force than is reasonably necessary in order to make an arrest."

1. I trust the police to investigate complaints against its own employees.

2. The police department investigates complaints fairly.

3. Police officers will choose to use the appropriate amount of force for an arrest.

4. The police department holds officers accountable for the unauthorized use of non-lethal weapons (i.e., TASER, ASP baton, OC pepper spray, etc.).

5. The police department holds officers accountable for the unauthorized use of lethal weapons (i.e., duty pistol or assault rifle).

6. Should an officer be suspected of using excessive force during an arrest, the police department will proceed with the appropriate investigative procedures.

7. Should an officer be charged with using excessive force during an arrest, he/she will be penalized appropriately.

Scoring: $1=$ strongly disagree to $5=$ strongly agree for all questions. Items are summed and higher scores indicate more specific trust in police use of force.

Strongly disagree

Somewhat disagree

Neither agree nor disagree

Somewhat agree

Strongly agree 


\section{Arrest Video Use of Force Questionnaire}

1. Please rate the intensity of this video.

1. Not at all intense

2. Slightly intense

3. Moderately intense

4. Very intense

1. What is your overall perception of the quality of the interaction between the law enforcement officer and the subject?

1. Very positive

2. Somewhat positive

3. Somewhat negative

4. Very negative

2. What was the gender of the officer?

1. Female

2. Male

3. What color was the subject's car?
1. Red
2. White
3. Black
4. Tan

4. Why did the officer arrest the subject?

1. The officer found a firearm in the subject's glove box.

2. The subject had a bench warrant.

3. The subject was caught fleeing the scene of an accident.

4. The officer found marijuana in the subject's pocket.

5. Please rate the appropriateness of the level of force used during the arrest:

1. Very appropriate use of force

2. Somewhat appropriate use of force

3. Somewhat excessive use of force

4. Very excessive use of force

6. Overall, would you rate this level of force as excessive?

1. No

2. Yes

7. Please briefly describe what it was that impacted your decision regarding the appropriateness of the level of force used during the arrest. 


\section{Appendix C}

Table 5

Demographic characteristics of pilot study participants.

\begin{tabular}{lrr}
\hline Characteristics & $\begin{array}{c}\text { Psychology students, } \\
\mathrm{n}=82\end{array}$ \\
\hline Age aggregate (years) & & \\
$17-24$ & 1 & $(97.6 \%)$ \\
$25-34$ & 1 & $(1.2 \%)$ \\
$35-44$ & 0 & $(0.0 \%)$ \\
$45-54$ & 0 & $(0.0 \%)$ \\
$55-64$ & 0 & $(0.0 \%)$ \\
65+ & & \\
Gender & 18 & $(22.0 \%)$ \\
Male & 64 & $(78.0 \%)$ \\
Female & & \\
Race & 69 & $(84.1 \%)$ \\
Caucasian/White & 5 & $(6.1 \%)$ \\
African-American/Black & 1 & $(1.3 \%)$ \\
American Indian/Alaskan Native & 6 & $(7.3 \%)$ \\
Asian & 0 & $(0.0 \%)$ \\
Native Hawaiian/Pacific Islander & 1 & $(1.3 \%)$ \\
Multiracial & 14.74 & $(1.94)$ \\
\hline Mean years of education (SD) & \multicolumn{3}{c}{} \\
\hline Relationship status & 76 & $(92.7 \%)$ \\
Single & 0 & $(0.0 \%)$ \\
Married & 4 & $(4.9 \%)$ \\
Living with another & 1 & $(1.2 \%)$ \\
Divorced & 0 & $(0.0 \%)$ \\
Widowed & 0 & $(0.0 \%)$ \\
Separated & 1 & $(1.2 \%)$ \\
Other & \multicolumn{2}{c}{} \\
\hline
\end{tabular}

